AN INTERNATIONAL FORUM FOR THE RAPID PUBLICATION OF ORIGINAL SCIENTIFIC ARTICLES DEALING WITH CHEMISTRY AND RELATED INTERDISCIPLINARY AREAS
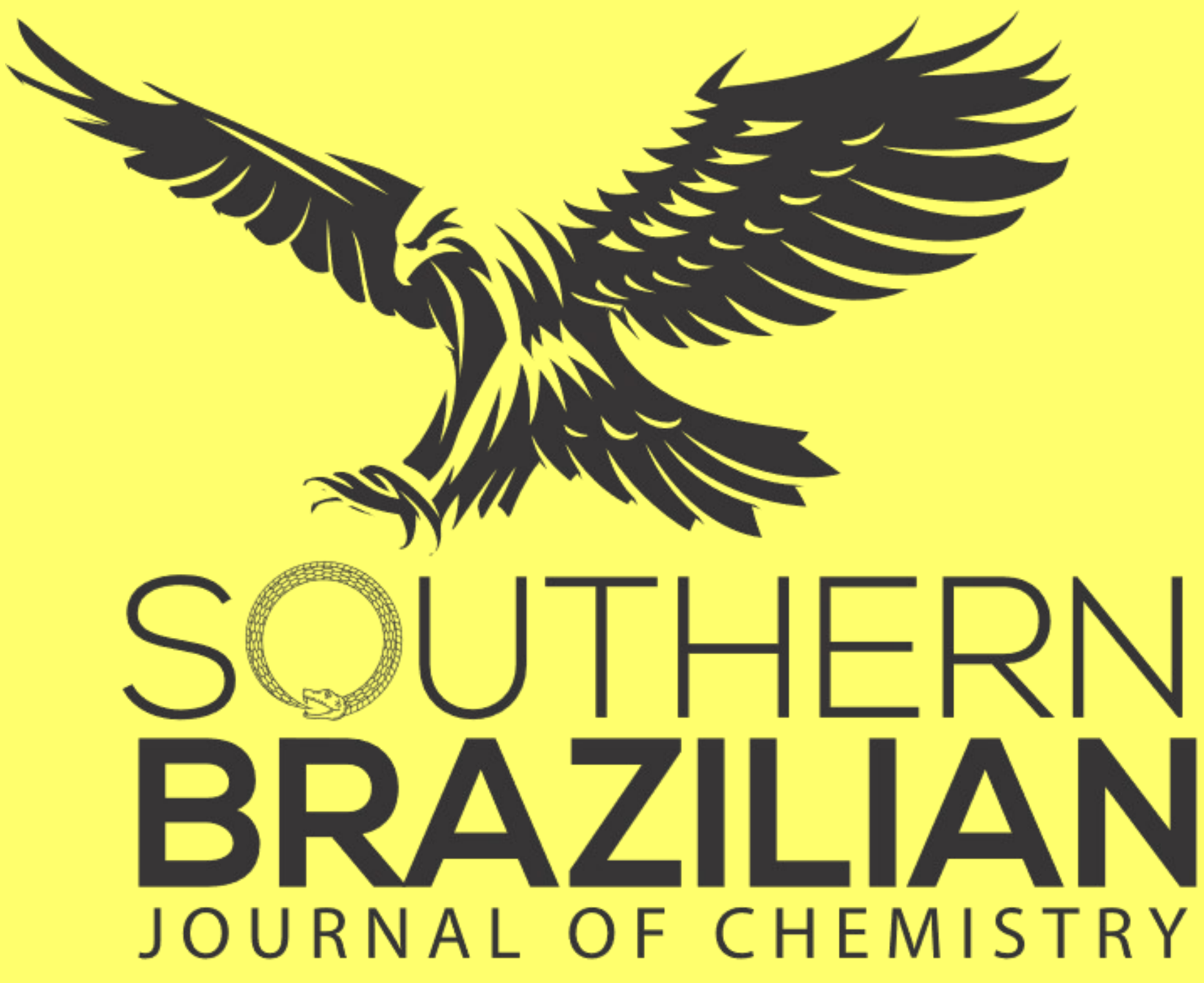

E S T A B L I S H E D I N 1993

VOLUME TWENTY-SEVEN, NUMBER TWENTY-SEVEN

ISSN 0104-5431 - E-ISSN 2674-6891 


\section{International Cataloging Data on Publication (CIP)}

SOUTHERN BRAZILIAN JOURNAL OF CHEMISTRY: órgão de divulgação científica e informativa [recurso eletrônico] / SOUTHERN BRAZILIAN JOURNAL OF CHEMISTRY - Vol. 25, n. 25 (Dec. 2017)- . - Porto Alegre: Grupo Tchê Química, 2017 - Anual.

Sistema requerido: Adobe Acrobat Reader.

Modo de acesso: World Wide Web:

<http://www.sbjchem.com>

Descrição baseada em: Vol. 25, n. 25 (Dec. 2017).

ISSN 0104-5431

1. Química. I. SOUTHERN BRAZILIAN JOURNAL OF CHEMISTRY.

CDD 500 


\section{SOUTHERN BRAZILIAN JOURNAL OF CHEMISTRY}

\section{Volume 27}

\section{Number $27-2019$}

ISSN: 0104-5431; E-ISSN: 2674-6891

\section{Editor-in-chief}

- Dr. Luis Alcides Brandini De Boni, Brazil, CORSAN, deboni@tchequimica.com

\section{Technical editors}

- Dr. Eduardo Goldani, goldani@tchequimica.com

- Ketevan Kupatadze, Dr., kupatadze@tchequimica.com , Geórgia, ISU

\section{Editorial Board}

- Rafael Rodrigues de Oliveira, Dr., oliveira@tchequimica.com, Brazil, Neoprospecta.

- Teresa M. Roseiro Maria Estronca, Dr., roseiro@tchequimica.com, Portugal, UC.

- Marcos Antônio Klunk, Dr., marcosak@edu.unisinos.br, Brazil, UNISINOS.

- Dr. Francisco José Santos Lima, lima@tchequimica.com , Brazil, UFRN.

- Monica Regina da Costa Marques, Dr., aguiar@tchequimica.com, Brazil, UERJ.

- Rodrigo Brambilla, Dr., brambilla@tchequimica.com, Brazil, UFRGS.

- Gabriel Rubensam, Me., grubensam@tchequimica.com, Brazil, PUCRS.

- Andrian Saputra, PhD., saputra@tchequimica.com, University of Lampung, Indonesia

- Zhanar Zhumadilova, Ph.D., zhanar85@@mail.ru, Satbayev University, Kazakhstan.

- Roberto Fernandez, Ph.D., rfernandezm@unicartagena.edu.co, Universidad de Cartagena, Colombia.
- Andrey Vladimirovich Sevbitov, avsevbitov@mail.ru, Ph.D., Russian Federation.

\section{SOUTHERN BRAZILIAN JOURNAL OF CHEMISTRY}

ISSN - 0104-5431 (Printed)

Eletronic ISSN: 2674-6891

\section{Available at}

http://www.sbjchem.com

\section{Mission}

\section{The SOUTHERN BRAZILIAN}

JOURNAL OF CHEMISTRY is a double-blind peer review, open access, multidisciplinary journal dedicated to publishing high-quality content and is intended to fill a gap in terms of scientific information for Southern Brazil. We have set high standards for the articles to be published by ensuring strong but fair refereeing by at least two reviewers. The Journal publishes original research articles in all the fields of Engineering, Mathematics, Physics, Chemistry, Biology, Agriculture, Natural resource management, Pharmacy, Medicine, and others.

Occasionally the journal will include review papers, interviews, and other types of communications. It will be published mainly in English, and at present, there are no page charges.

We hope that this journal will provide a forum for the dissemination of high-quality research in Science and are open to any questions and suggestions.

The responsibility for the articles is exclusive to the authors.

\section{Correspondências}

Rua Francisco Schneider, 292/302.

Bairro Centro. CEP: 95320-000

Nova Prata - RS. Brasil.

Skype: tchequimica

www.sbjechem.com

southbchem@gmail.com 


\title{
INVESTIGATION OF PHOSPHATE-ION RETENTION STRENGHT IN SOME TYPES OF KAKHETI SOILS
}

\author{
KUPATADZE, Ketevan
}

${ }^{1}$ Ullia State University, Faculti of Natural Science and Medicine. Georgia.

\begin{abstract}
The presented article describes the soil types existing in east Georgia, particularly in several villages of Gurjaani Municipality-Vazisubani, Kalauri, Mukuzani, Shashiani. Meadow-brown and brown soils represent good soil types for viticulture development in Kakheti. The vineyards cultivated on these soils produce such well-known wines as Tsinandali, Vazisubani, Mukuzani, Akhasheni, Gurjaani, Manavi. The study explores brown carbonate and meadow-brown soil lab tests to examine the absorption of phosphate ions by them. The study showed that the amount of phosphorus deposited through soils is sufficiently absorbed under various conditions, having a positive effect on the amount of crop. Was compared the rates of phosphate absorption in these soils with the efficiency of phosphorus fertilizers, which showed that the higher the absorption of phosphorus, the lower the amount of phosphorus available to the plant and the lower the yield, and the lower the strength of phosphorus retention, the higher the amount of phosphorus to be consumed by the plant and the higher the yield. But under the conditions of high cultivation degree, the strength of phosphorus absorption became weak, resulted in a large amount of exchangeable and movable phosphates already existing in the soil, which is available to the plant. So, the efficacy of phosphorus fertilizers on such soil is weak. The speed of phosphorus absorption in the soil of Gurjaani municipality villages is satisfactory. However, in case of a high degree of cultivation (or in case of excess fertilization), the degree of phosphorus retention decreases. Accordingly, phosphorus-containing fertilizers should be used within strictly controlled limits.
\end{abstract}

Page - 1

\section{BUNCH NUMBER AND ANTIOXIDANT ACTIVITY IN 'SAHEBI' AND 'HALAGHO' GRAPES AFFECTED BY PRUNING INTENSITY AND CANE LENGTH}

\section{MAHTAB, Zonouri' ${ }^{*}$; DAVOOD, Bakhshi²; ESMAEIL, Fallahi³; ISA, Arji ${ }^{4}$}

${ }^{1}$ University of Guilan, Faculty of Agricultural Sciences, University Campus 2, Department of Horticultural Science. Iran ${ }^{2}$ University of Guilan, Faculty of Agricultural Sciences, Department of Horticultural Science. Iran ${ }^{3}$ University of Idaho, Pharma Research and Extension Center, Pharma. The USA ${ }^{4}$ Agricultural and Natural Resources Research and Education Center, Department of Crop, and Horticultural Science Research. Iran

\section{ABSTRACT}

Pruning methods can primarily affect grape production at various levels. Of the commonly affected features by pruning, the number of bunches has known to have a significant effect on the relation between the functions of assimilate sources and sinks. Further, fruitfulness can significantly be negatively influenced by shading. In this study, we aim to study the impact of 4,6 and 8 buds per cane with pruning intensity as light, moderate and severely pruned and their interaction in the course two consecutive years, 2017 and 2018 in 'Sahebi' and 'Halagho' (both seeded red table grape cultivars). In 2018, lightly pruned 'Halagho' and having 8 buds per cane increased number of bunches by 54.00, which had the highest value. Results showed that there is apical buds bear more fruit by comparison to the buds with vegetative nature, 1 to 4 first buds. Based upon the outcomes of this study, it could be concluded that due to the stresses imposed by the pruning of the vines, therefore, the chemical compounds increases in order alleviate the negative aftermaths . In 2018, whole berry antioxidant activity in both cultivars was significantly lessened, and this decline was higher in 'Saahebi'. The number of bunches was increased by increasing cane length or bud load/cane. Overall, the pruning program has an impactful role in bunch number as well as antioxidant activity and in the long-run on accumulated reserves, which makes choosing and applying a specific pruning method undeniably important. Thus, emphasize the importance of further research in this field. 


\title{
INDICATORS OF TRYPSIN-LIKE ACTIVITY OF MIXED SALIVAAFTER INSTALLING THE ENDOSSEOUS IMPLANTS IN THE PRESENCE OF GASTRIC ULCER AND DUODENAL ULCER
}

\author{
KUZNETSOVA, Mariya, NIKONOVA, Anna; KUZNETSOV, Ivan; SEVBITOVA, Mariya; TIMOSHINA, \\ Mariya
}

${ }^{1}$ Department of Propaedeutic of Dental Diseases of I. M. Sechenov First Moscow State Medical University (Sechenov University)

\begin{abstract}
The trypsin-like activity of mixed saliva in orthopedic patients after implant placement was monitored. Proved negative impact on the processes of repair of background somatic pathology (peptic ulcers and 12 duodenal ulcers), justify the application of immunomodulator "Erbisol" as a drug that speeds up the repair processes during implantation. At present, the relevant issues are those related to the development of inflammatory complications at the stage of rehabilitation of patients, especially in the presence of somatic pathology and the study of the tissue complex of the implantation zone. Peptic ulcer disease occupies one of the main places in the structure of lesions of the digestive system. The close interdependence between the pathology of internal organs and the oral cavity is confirmed by numerous observations and studies. Implant placement is accompanied by changes in the enzymatic activity of mixed saliva. The presence of somatic pathology (ulcerative disease of the stomach and 12 duodenal ulcers) often leads to more long-term violations of the enzymatic activity of saliva. The use of the drug "Erbisol" in orthopedic dentistry accelerates the repair process, as evidenced by the earlier periods of normalization of the enzymatic activity of mixed saliva, after the installation of implants.Regular and timely monitoring of the condition of the periarticular tissues, as well as objective diagnosis of early inflammatory complications, are necessary to ensure the reliability and long-term functioning of prosthetic structures installed on implants in the oral cavity.It can be concluded that the purpose of our study was to study the trypsin-like activity (TPA) of mixed saliva after implant placement on the background of somatic pathology..
\end{abstract}

Page - 13

\section{NIOBIUM ALLOY STEEL APPLIED IN COLD FORMING MANUFACTURE}

\author{
MAIA, Bruno Inácio; FUTAMI, André Hideto'; DE OLIVEIRA, Marco Aurélio; DALLA VALENTINA, Luiz \\ Veriano Oliveira ${ }^{1}$ \\ ${ }^{1}$ Centro Universitário SOCIESC - UNISOCIESC, Mestrado em Engenharia de Produção, Departamento de Pesquisa.
} Brazil

\section{ABSTRACT}

Niobium alloy steels are still little known and debated when applied to the metallurgy industry, including cold forming process. It is not much clear about its characteristics and your mechanical performance when compared to traditional steels, which the market already uses. The possibility of input new materials, reducing costs and generating competitiveness is the basis for researches that can generate new opportunities for industries. In this article, we showed the possibility of withdrawing the heat treatment process, which guided the execution of the tests presented here. This paper deals with the performance comparison of SAE 1312 MOD steel compared to ISO 898-1, which deals with mechanical performance for bolts. The tests were correlated with the bolts of 8.8 resistance class, which currently have heat treatment. It is possible to evaluate the positive performance of the niobium-alloyed steel (SAE 1312 MOD), despite the occasional performance limitations in some attributes addressed in ISO 898-1. 


\title{
PRODUCTION OF BIOPLASTIC FROM POTATO STARCH
}

\section{CORDEIRO, Paula Novais'; CAETANO, Skarllet Toledo'; DE CARVALHO, Raquel Moreira Maduro1}

\author{
${ }^{1}$ Departamento de Engenharia Química, União de Ensinos Superiores de Viçosa, Viçosa, MG.Brazil.
}

\begin{abstract}
Due to their diverse properties, plastic materials are used in numerous sectors. It is possible to produce different articles and plastic objects with reduced costs, being more accessible to the population. Conventional plastics are obtained from petroleum-derived raw materials, a non-renewable resource in which their extraction and refining process cause major environmental impacts. The production of plastic reaches a level of approximately one hundred and forty million tons per year, and the disposal of these materials is increasing, generating a high rate of waste and leading to an increase of pollution since the decomposition of these materials lasts about five hundred years old. Conventional plastics can be replaced by bioplastics, a material obtained from renewable raw materials such as potatoes, cassava, maize, and which, when disposed of under favorable conditions, decomposes faster, as during its degradation process at least one step occurs. Through the metabolism of organisms present in the environment. Starch has been widely used in the production of biodegradable packaging, so the objective of this work was to produce a biodegradable bioplastic from the potato starch. Potato starch, glycerin, hydrogen peroxide, distilled water, and commercial agar were used to produce the bioplastic. Bench-scale bioplastics had good organoleptic characteristics, similar in appearance to a conventional plastic obtained from petroleum. The thickness, moisture content, and solubility of the bioplastics were analyzed, as well as their fruit preservation capacity. The samples produced were rigid and with good resistance.
\end{abstract}

Page - 30

\section{TO AUTHORS}

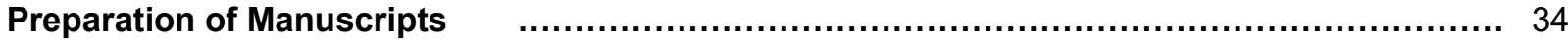

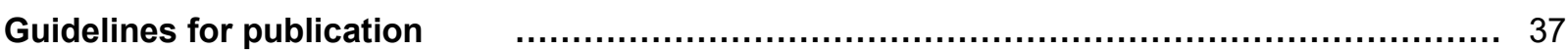

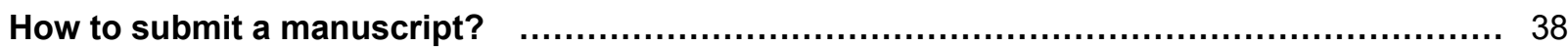




\title{
SOUTHERN BRAZILIAN JOURNAL OF CHEMISTRY
}

\section{INVESTIGATION OF PHOSPHATE-ION RETENTION STRENGHT IN SOME TYPES OF KAKHETI SOILS}

\author{
KUPATADZE, Ketevan*; \\ Ilia State University, Faculti of Natural Science and Medicine. Georgia \\ e-mail: ketevan_kupatadze@iliauni.edu.ge
}

Received 12 July 2019; received in revised form 30 September 2019; accepted 21 October 2019

\begin{abstract}
The presented article describes the soil types existing in east Georgia, particularly in several villages of Gurjaani Municipality-Vazisubani, Kalauri, Mukuzani, Shashiani. Meadow-brown and brown soils represent good soil types for viticulture development in Kakheti. The vineyards cultivated on these soils produce such wellknown wines as Tsinandali, Vazisubani, Mukuzani, Akhasheni, Gurjaani, Manavi. The study explores brown carbonate and meadow-brown soil lab tests to examine the absorption of phosphate ions by them. The study showed that the amount of phosphorus deposited through soils is sufficiently absorbed under various conditions, having a positive effect on the amount of crop. Was compared the rates of phosphate absorption in these soils with the efficiency of phosphorus fertilizers, which showed that the higher the absorption of phosphorus, the lower the amount of phosphorus available to the plant and the lower the yield, and the lower the strength of phosphorus retention, the higher the amount of phosphorus to be consumed by the plant and the higher the yield. But under the conditions of high cultivation degree, the strength of phosphorus absorption became weak, resulted in a large amount of exchangeable and movable phosphates already existing in the soil, which is available to the plant. So, the efficacy of phosphorus fertilizers on such soil is weak. The speed of phosphorus absorption in the soil of Gurjaani municipality villages is satisfactory. However, in case of a high degree of cultivation (or in case of excess fertilization), the degree of phosphorus retention decreases. Accordingly, phosphorus-containing fertilizers should be used within strictly controlled limits.
\end{abstract}

Keywords: Soil, Environmental chemistry, absorbtion of phosphate ions;

\section{INTRODUCTION}

In the 21st century, the UN Commission has put a special emphasis on the fight for cleanliness, elimination of hunger and poverty in the presented agenda for Sustainable Development (Orgill, 2019; Mahaffy, 2019). Haber-Bosch process for the synthesis of ammonia is considered to be one of the basic discoveries of the twentieth century, as the crop productivity is a true way to fight against hunger, that can be achieved by proper and moderate use of fertilizers. Therefore, the chemical composition of the soil from environmental chemistry is of particular importance, as the expected amount of the crop and cleanliness of food products are directly related to its composition (McMurry, 2015).

Georgia is a mountainous country in the Caucasus, neighboring Russia, Azerbaijan,
Armenia, and Turkey. Georgia is characterized by a great variety of soil types on its small territory, which includes nearly all soils of the world (Sabashvili, 1965; Urushadze, 2014; Guide of Georgian Soils, 2014; Guide of Soils, 2015).

Specifically, types of soil in Georgia: Mountain-meadow, reddish, yellowish, marshy, brown, black, salt marshy, saline soils, and more. The following soils are spread all over the East of Georgia: valley-brown, black, bushy, alluvial soils; Carbonated, mountain black, mountain-forestmeadow, and mountain-meadow soils (Urushadze, 2015; Sabashvili, 1965). Meadowbrown and brown soils represent good soil types for viticulture development in Kakheti. The vineyards cultivated on these soils produce such well-known wines as Tsinandali, Vazisubani, Mukuzani, Akhasheni, Gurjaani, and Manavi.

Brown soils are characterized by granularrocky structure, skeletal structure, good physical, 
thermal, watery and biological properties; high content of carbonates, up to $93 \%$, with a neutral and alkali reaction of $\mathrm{PH}-7.0-8.0$ ); Clay and light clay mechanical composition, high absorption capacity; Humus - 3-7\%; Total nitrogen - 0.05$0.4 \% ; 0.8 \%$ of total potassium, with a low content of iron and manganese. Lately, more attention has been paid to organic phosphorus of the soil, as a potential supply of phosphorus to the plant. $10-80 \%$ of the total phosphorus is in the arable soil. The speed and amount of organic phosphorus production depend on the type of soil production, environmental conditions, and anthropological factors. The systematic application of fertilizers increases organic content of phosphorus. According to available data, phosphorus content in soil does not change by adding mineral fertilizers (Wandruszka,2006; Solomon, 2000; Whalen, 2001). Generally, phosphorus-rich soils are almost absent. The amount of movable phosphorus is low in Georgian soils. It can be found in the form of calcium and magnesium phosphates in carbonate soils. They are then converted to semi-soluble and soluble phosphates and thus are absorbed by plants. The progress of this process is very limited, so phosphorus-containing mineral and organic fertilizers are needed (Pierzynski,2000).

\section{MATERIALS AND METHODS}

In order to explore carbonaceous and meadow-brown soils of eastern Georgia, we conducted laboratory tests to study the absorption of phosphate ions. In 2018, soil samples were taken in the villages of the Gurjaani district of Kakheti: Vazisubani, Kalauri, Mukuzani, Shashiani (Figures 1 and 2). Gurjaani is a municipality of Kakheti region in eastern Georgia (Kartlis tskovreba, 2014). The territory of Gurjaani municipality belongs to moderate humid subtropical climate district. The moderately humid climate is formed on the plain in the east, with mild winters and hot summers. The climate on Gombori Range is moderately humid, with a long summer. The average annual temperature is $12.4{ }^{\circ} \mathrm{C}$, the average temperature in January, coldest month of the year, is $0.11 \mathrm{C}$, and in August, the hottest month - the annual temperature is $35.8{ }^{\circ} \mathrm{C}$. A.The average annual volume of precipitation in the major part of the area is up to $800 \mathrm{~mm}$ and decreases to $500-600 \mathrm{~mm}$ upstream. In the article (Kupatadze, 2018) is presented the studies on water samples from these villages. Naturally, soil investigation was also an issue of interest. The samples were taken at a depth of $0-40 \mathrm{~cm}$.

\subsection{Method of experiment}

We placed $10 \mathrm{~g}$ soil sifted through $1 \mathrm{~mm}$ diameter sieve in a conic flask and added $50 \mathrm{ml}$ of an aqueous solution of calcium $\mathrm{Ca}\left(\mathrm{H}_{2} \mathrm{PO}_{4}\right) 2 \cdot \mathrm{H}_{2} \mathrm{O}$. We took the series of a solution with different concentrations 20,40,60,80,160, and 200mg $\mathrm{P}_{2} \mathrm{O}_{5}$ in one litre of water, i.e. we added 10, 20, $30,40,60,80$ and $10 \mathrm{mg} \mathrm{P}_{2} \mathrm{O}_{5}$ per $100 \mathrm{gr}$ of soil. The first batch of weight was delayed for one day, the second batch - for three days, the third batch - for six days. We used to shake the flanks periodically. We added 7 drops of $0.2 \%$ sodium azides solution as an antiseptic to each flask. After passing some time, we shook the suspension for five minutes and filtered. The phosphorus was determined by calorimeter method (Williams, 2012. VanLoon, 2011) and the phosphorus moving in the residual soil was defined by Lorenz - Schaefer method (Daughton, 2004; Liu, 2009; Pierzynski, 2000; Turner, 2003; Lehmann, 2005.) (Tables 1, 2, 3).

The studied soils are characterized by a high absorption capacity of phosphate ions. After three days of interaction, the absorbed phosphorus was more than $99 \%$ of the input and more than $99.5 \%$ after six days.

Indicators of $\mathrm{P}_{2} \mathrm{O}_{5}$ concentration $(\mathrm{mg} / \mathrm{L})$ given in Table 1,2,3 characterize the degree of movement of the absorbed phosphorus, i.e., its ability to move from soil to saline (intensity factor). We conducted a second laboratory test to study phosphate absorption in red, brown carbonate, and meadow-brown soils. We prepared the compost in a glass container of $500 \mathrm{~g}$ soil capacity. we added calcium monophosphate (as a solution) to the soil by 10 , $20,30,40,60$, and $80 \mathrm{mg}$ of $\mathrm{P}_{2} \mathrm{O}_{5}$ per $100 \mathrm{~g}$ of soil. Phosphates in soil were defined in $0.01 \mathrm{~N}$ $\mathrm{CaCl}_{2}, \quad 0.01 \mathrm{~N}_{2} \mathrm{H}_{2}$, and $1 \% \quad\left(\mathrm{NH}_{4}\right)_{2} \mathrm{CO}_{3}$ solutions, one day, 1.5, 3, 6 months and 1 year after phosphate application. We calculated the phosphorus retention strength by the percentage of phosphorus excreted and deposited (Table $4,5,6)$. The intensity of phosphate absorption depends on the dosages of phosphorus added. At low doses $(10-40 \mathrm{mg} / 100 \mathrm{~g})$, the phosphorus retention strength is high and after one year of composting, it ranges between $74.2-80 \%$ for all 
three types of soils. At high dose levels $(60-80 \mathrm{mg}$ $/ 100 \mathrm{~g}$ ) it varies between $62.6-70 \%$. These values are relatively high in red soil - 65-70\%. 62.6-65.5 and $63-66 \%$ are in brown-carbonate and meadow-brown soils. In the range of $10-40 \mathrm{mg}$ concentration per $\mathrm{P}_{2} \mathrm{O}_{5} / 100 \mathrm{~g}$ of soil, we got practically identical phosphorus retention strength indicators for all three types of soil. This allows us to use any of these doses (10 to $40 \mathrm{mg}$ ) to determine the strength of the phosphorus retention.

\section{RESULTS AND DISCUSSION:}

We compared the rates of phosphate absorption in these soils with the efficiency of phosphorus fertilizers, which showed that the higher the absorption of phosphorus, the lower the amount of phosphorus available to the plant and the lower the yield, and vice versa, the lower the strength of phosphorus retention, the higher the amount of phosphorus to be consumed by the plant and the higher the yield. (Table 7). Based on the indicator of phosphorus retention strength, obtained on these soils, we consider it possible to make a qualitative assessment of these indicators;

Specifically, it corresponds to the amount of phosphorus excreted, expressed as a percentage of deposited fertilizer, calculated as $10-40 \mathrm{mg}$ $\mathrm{P}_{2} \mathrm{O}_{5}$ in $100 \mathrm{~g}$ of soil, by 6-month interaction with the soil under the conditions of $60 \%$ humidity and $20-25^{\circ} \mathrm{C}$. Diagnostic Table 8 has been developed to determine the quality of soil caltivation and efficiency of phosphorus fertilizer according to the phosphorus retention strength indicator. If $\mathrm{P}_{2} \mathrm{O}_{5}$ excretion is less than $30 \%$, then the soil intensively absorbs phosphorus, and they are firmly bonded. Under the following indexes: 30 $50 \%$ firm; $50-70 \%$ average, $70-80 \%$ weak. As for the phosphorus movement, the same will change in the opposite order. Therefore, under the conditions of high cultivation degree, the strength of phosphorus absorption is very weak, resulted in a large amount of exchangeable and movable phosphates already existing in the soil, which is available to the plant. Therefore, the efficacy of phosphorus fertilizers on such soil is weak.

\section{CONCLUSIONS:}

According to the study, the consumption rate of phosphorus in the soil of Gurjaani municipality villages is satisfactory. However, in case of a high degree of cultivation (or in case of excess fertilization), the degree of phosphorus retention decreases. Accordingly, phosphoruscontaining fertilizers should be used within strictly controlled limits.

\section{REFERENCES:}

1. Orgill,M., York, S., Mackellar, J. J.of Chemical Education, 2019, 22, 234.

2. Mahaffy, P., Stephen, A., Thomas, A. Nature Suistability, 2019, 2,362.

3. McMurry,J. Organic Chemistry,Cengage Learning, 2015, 654.

4. Sabashvili, M., "Metsniereba", Tbilisi, $1965,549$.

5. Urushadze, T., Blum, W. "Nova",New York, 2014, 242.

6. Guide of Georgian Soils., "Mtsignobari", Tbilisi, 2014, 135.

7. Guide of Soils., Swiss Cooperation Office South, 2015, 50.

8. Urushadze, T., Winfried, E., Blum, J. Annals of Agrarian Science, 2015, 13,4.

9. Sabashvili, M. "Metsniereba", Tbilisi, 1965,549 .

10. Wandruszka, R. Geochemical Transactions, 2006, 7(1),6.

11. Solomon, D., Lehmann, J. European J. of Soil Science, 2000, 51, 699.

12. Whalen, J., Chang,C.J.Of Environmental Quality, 2001, 30, 229.

13. Pierzynski, G. Eur. J. Biochem, 2000, $51,253$.

14. Topoarchaeological dictionary of Kartlis tskovreba (The History of Georgia)., Tbilisi: Georgian National Museum. 2014.

15. Kupatadze, K. Southern Brazilian Journal of Chemistry, 2018, 26, 26.

16. Williams, J. Envinronmental, Chemistry; J.Wiley \&amp; Sons. Canada. 2012, 7, 128.

17. VanLoon, J. Envinronmental, Chemistry-a global perspective.Oxford Group.2011,3, 78.

18. Daughton, Ch.; Environmental Impact Assessment Review. 2004. 7, 711-732.

19. Liu, H. J. of Public Health., 2009, 31, 32 38.

20. Pierzynski, G. Southern Cooperative Series Bulletin. 2000. 396.

21. Turner,B.,Mahjeu,N. Soil Science Society of America J. 2003. 67, 497.

22. Lehmann,J.,Lan,Z.,Hyland,C. Environmental Science \&Technology. 
2005. 39, 6672 .

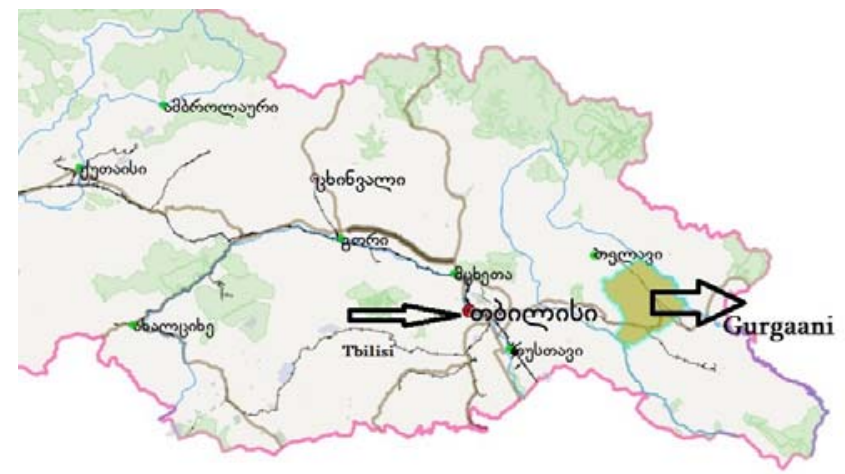

Figure 1. Gurjaani district

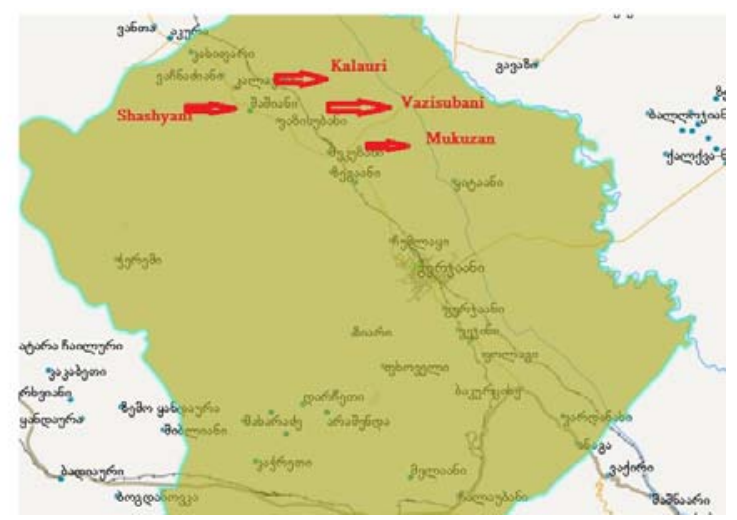

Figure 2. Villages in Gurjaani district

Table 1. Interaction of the soil with phosphate solutions and indicators of the movement of absorbed phosphates

\begin{tabular}{|c|c|c|c|c|c|c|}
\hline \multirow[t]{2}{*}{$\begin{array}{l}\text { Giving } \mathrm{P}_{2} \mathrm{O}_{5} \text { (solution) } \\
\text { mg/100g soil }\end{array}$} & \multicolumn{3}{|c|}{$\begin{array}{l}\mathrm{P}_{2} \mathrm{O}_{5} \mathrm{mg} / \mathrm{l} \\
0,01 \mathrm{NCaCl}{ }_{2} \text { solution }\end{array}$} & \multicolumn{3}{|c|}{$\mathrm{P}_{2} \mathrm{O}_{5} \mathrm{mg} / 100$ I soil } \\
\hline & $\begin{array}{l}\text { After } 1 \\
\text { day }\end{array}$ & $\begin{array}{l}\text { After 3 } \\
\text { day }\end{array}$ & $\begin{array}{l}\text { After } 6 \\
\text { day }\end{array}$ & $\begin{array}{l}\text { After } 1 \\
\text { day }\end{array}$ & After 3 day & After 6 day \\
\hline 1 & 2 & 3 & 4 & 5 & 6 & 7 \\
\hline \multicolumn{7}{|l|}{ reddish (uncultivated) } \\
\hline $\begin{array}{l}\text { Without phosphorous; Control } \\
10 \\
20 \\
30 \\
40 \\
60 \\
80 \\
100\end{array}$ & $\begin{array}{l}0,008 \\
0,020 \\
0,036 \\
0.040 \\
0.050 \\
0.070 \\
0,080 \\
0,11\end{array}$ & $\begin{array}{l}0,008 \\
0,016 \\
0,028 \\
0.032 \\
0.037 \\
0.046 \\
0,056 \\
0,075\end{array}$ & $\begin{array}{l}0,008 \\
0,016 \\
0,026 \\
0.030 \\
0.035 \\
0.042 \\
0,050 \\
0,072\end{array}$ & $\begin{array}{l}2,2 \\
6,6 \\
13,0 \\
18,4 \\
28,0 \\
42,8 \\
64,0 \\
85,0\end{array}$ & $\begin{array}{l}2,2 \\
6,4 \\
11,0 \\
15,0 \\
22,5 \\
35,0 \\
50,0 \\
70,0\end{array}$ & $\begin{array}{l}2,2 \\
6,2 \\
8,7 \\
13,0 \\
18,0 \\
26,0 \\
40,0 \\
52,0\end{array}$ \\
\hline
\end{tabular}


Table 2. Interaction of the soil with phosphate solutions and indicators of the movement of absorbed phosphates

\begin{tabular}{|c|c|c|c|c|c|c|}
\hline \multirow[t]{2}{*}{$\begin{array}{l}\text { Giving } \mathrm{P}_{2} \mathrm{O}_{5} \text { (solution) } \mathrm{mg} / 100 \mathrm{~g} \\
\text { soil }\end{array}$} & \multicolumn{3}{|c|}{$\begin{array}{l}\mathrm{P}_{2} \mathrm{O}_{5} \mathrm{mg} / \mathrm{l} \\
0,01 \mathrm{NCaCl}{ }_{2} \text { solution }\end{array}$} & \multicolumn{3}{|c|}{$\mathrm{P}_{2} \mathrm{O}_{5} \mathrm{mg} / 100$ I soil } \\
\hline & $\begin{array}{l}\text { After } 1 \\
\text { day }\end{array}$ & $\begin{array}{l}\text { After } 3 \\
\text { day }\end{array}$ & $\begin{array}{l}\text { After } 6 \\
\text { day }\end{array}$ & $\begin{array}{l}\text { After } 1 \\
\text { day }\end{array}$ & After 3 day & $\begin{array}{l}\text { After } 6 \\
\text { day }\end{array}$ \\
\hline 1 & 2 & 3 & 4 & 5 & 6 & 7 \\
\hline \multicolumn{7}{|l|}{ Brown Carbonated (uncultivated) } \\
\hline $\begin{array}{l}\text { Without phosphorous; Control } \\
10 \\
20 \\
30 \\
40 \\
60 \\
80 \\
100\end{array}$ & $\begin{array}{l}0,012 \\
0,027 \\
0,054 \\
0.11 \\
0.19 \\
0.43 \\
1,1 \\
1,5\end{array}$ & $\begin{array}{l}0,012 \\
0,018 \\
0,040 \\
0.59 \\
0.1 \\
0.038 \\
0,68 \\
0,75\end{array}$ & $\begin{array}{l}0,012 \\
0,018 \\
0,037 \\
0.053 \\
0.075 \\
0.036 \\
0,59 \\
0,73\end{array}$ & $\begin{array}{l}1,2 \\
9,4 \\
18,4 \\
26,7 \\
34,3 \\
46,7 \\
78,7 \\
97,4\end{array}$ & $\begin{array}{l}1,2 \\
8,1 \\
15,5 \\
20,5 \\
29,0 \\
43,4 \\
69,9 \\
82,5\end{array}$ & $\begin{array}{l}1,2 \\
7,2 \\
11,4 \\
16,9 \\
24,5 \\
40,9 \\
52,5 \\
65,7\end{array}$ \\
\hline
\end{tabular}

Table 3. Interaction of the soil with phosphate solutions and indicators of the movement of absorbed phosphates

\begin{tabular}{|c|c|c|c|c|c|c|}
\hline \multirow[t]{2}{*}{$\begin{array}{l}\text { Giving } \mathrm{P}_{2} \mathrm{O}_{5} \text { (solution) } \mathrm{mg} / 100 \mathrm{~g} \\
\text { soil }\end{array}$} & \multicolumn{3}{|c|}{$\begin{array}{l}\mathrm{P}_{2} \mathrm{O}_{5} \mathrm{mg} / \mathrm{l} \\
0,01 \mathrm{NCaCl}{ }_{2} \text { solution }\end{array}$} & \multicolumn{3}{|c|}{$\mathrm{P}_{2} \mathrm{O}_{5} \mathrm{mg} / 100$ I soil } \\
\hline & $\begin{array}{l}\text { After } 1 \\
\text { day }\end{array}$ & After 3 day & $\begin{array}{l}\text { After } 6 \\
\text { day }\end{array}$ & $\begin{array}{l}\text { After } 1 \\
\text { day }\end{array}$ & After 3 day & $\begin{array}{l}\text { After } 6 \\
\text { day }\end{array}$ \\
\hline 1 & 2 & 3 & 4 & 5 & 6 & 7 \\
\hline \multicolumn{7}{|l|}{ meadow brown (uncultivated) } \\
\hline $\begin{array}{l}\text { Without phosphorous; Control } \\
10 \\
20 \\
30 \\
40 \\
60 \\
80 \\
100\end{array}$ & $\begin{array}{l}0,010 \\
0,025 \\
0,051 \\
0.1 \\
0.17 \\
0.42 \\
1,0 \\
1,3\end{array}$ & $\begin{array}{l}0,010 \\
0,016 \\
0,037 \\
0.055 \\
0.095 \\
0.35 \\
0,56 \\
0,72\end{array}$ & $\begin{array}{l}0,010 \\
0,016 \\
0,035 \\
0.054 \\
0.080 \\
0.32 \\
0,54 \\
0,71\end{array}$ & $\begin{array}{l}1,0 \\
9,0 \\
18,2 \\
24,8 \\
32,0 \\
44,9 \\
76,4 \\
96,2\end{array}$ & $\begin{array}{l}1,0 \\
7,9 \\
15,0 \\
19,7 \\
27,0 \\
42,5 \\
67,8 \\
81,0\end{array}$ & $\begin{array}{l}1,0 \\
7,0 \\
11,0 \\
16,3 \\
23,0 \\
39,8 \\
52,0 \\
63,8\end{array}$ \\
\hline
\end{tabular}

Table 4. Strength of absorbed phosphorus retention under laboratory test conditions (composts) 2018

\begin{tabular}{|c|c|c|c|c|c|}
\hline \multirow{2}{*}{$\begin{array}{l}\text { Giving } \mathrm{P}_{2} \mathrm{O}_{5} \text { (solution) } \mathrm{mg} / 100 \mathrm{~g} \\
\text { soil }\end{array}$} & \multicolumn{5}{|c|}{ Absorbed $\mathrm{P}_{2} \mathrm{O}_{5} \%$} \\
\hline & $\begin{array}{l}\text { After } 1 \\
\text { day }\end{array}$ & $\begin{array}{l}\text { After } \\
1,5 \text { month }\end{array}$ & $\begin{array}{l}\text { After } 3 \\
\text { month }\end{array}$ & $\begin{array}{l}\text { After } 6 \\
\text { month }\end{array}$ & After 1 year \\
\hline 1 & 2 & 3 & 4 & 5 & 6 \\
\hline \multicolumn{6}{|l|}{ reddish } \\
\hline \multicolumn{6}{|l|}{ Without phosphorous; Control } \\
\hline $\begin{array}{l}10 \\
20 \\
30 \\
40 \\
60 \\
80\end{array}$ & $\begin{array}{l}36 \\
32 \\
28 \\
24 \\
21 \\
18\end{array}$ & $\begin{array}{l}48 \\
44 \\
40 \\
38 \\
31 \\
28\end{array}$ & $\begin{array}{l}65 \\
64 \\
62 \\
59,5 \\
49,5 \\
48,7\end{array}$ & $\begin{array}{l}76 \\
76 \\
73 \\
72 \\
68 \\
63\end{array}$ & $\begin{array}{l}80 \\
80 \\
78 \\
77 \\
70 \\
65\end{array}$ \\
\hline
\end{tabular}


Table 5. Strength of absorbed phosphorus retention under laboratory test conditions (composts) 2018

\begin{tabular}{|c|c|c|c|c|c|}
\hline \multirow{2}{*}{$\begin{array}{l}\text { Giving } \mathrm{P}_{2} \mathrm{O}_{5} \text { (solution) } \mathrm{mg} / 100 \mathrm{~g} \\
\text { soil }\end{array}$} & \multicolumn{5}{|c|}{ Absorbed $\mathrm{P}_{2} \mathrm{O}_{5} \%$} \\
\hline & $\begin{array}{l}\text { After } 1 \\
\text { day }\end{array}$ & $\begin{array}{l}\text { After } \\
1,5 \text { month }\end{array}$ & $\begin{array}{l}\text { After } 3 \\
\text { month }\end{array}$ & $\begin{array}{l}\text { After } 6 \\
\text { month }\end{array}$ & After 1 year \\
\hline 1 & 2 & 3 & 4 & 5 & 6 \\
\hline \multicolumn{6}{|l|}{ Brown Carbonated } \\
\hline \multicolumn{6}{|l|}{ Without phosphorous; Control } \\
\hline $\begin{array}{l}10 \\
20 \\
30 \\
40 \\
60 \\
80\end{array}$ & $\begin{array}{l}32,0 \\
29,0 \\
23,5 \\
21,5 \\
17,2 \\
12,5\end{array}$ & $\begin{array}{l}44,0 \\
37,0 \\
32,5 \\
31,5 \\
26,0 \\
23,0\end{array}$ & $\begin{array}{l}62,0 \\
61,0 \\
59,5 \\
58,0 \\
45,5 \\
44,0\end{array}$ & $\begin{array}{l}74,0 \\
73,0 \\
71,5 \\
70,0 \\
62,0 \\
59,5\end{array}$ & $\begin{array}{l}78,0 \\
77,0 \\
74,5 \\
74,2 \\
65,5 \\
62,6\end{array}$ \\
\hline
\end{tabular}

Table 6. Strength of absorbed phosphorus retention under laboratory test conditions (composts) 2018

\begin{tabular}{|c|c|c|c|c|c|}
\hline \multirow{2}{*}{$\begin{array}{l}\text { Giving } \mathrm{P}_{2} \mathrm{O}_{5} \text { (solution) } \mathrm{mg} / 100 \mathrm{~g} \\
\text { soil }\end{array}$} & \multicolumn{5}{|c|}{ Absorbed $\mathrm{P}_{2} \mathrm{O}_{5} \%$} \\
\hline & $\begin{array}{l}\text { After } 1 \\
\text { day }\end{array}$ & & $\begin{array}{l}\text { After } 1 \\
\text { day }\end{array}$ & & After 1 day \\
\hline 1 & 2 & 3 & 4 & 5 & 6 \\
\hline \multicolumn{6}{|l|}{ meadow brown } \\
\hline \multicolumn{6}{|l|}{ Without phosphorous; Control } \\
\hline $\begin{array}{l}10 \\
20 \\
30 \\
40 \\
60 \\
80\end{array}$ & $\begin{array}{l}34 \\
30 \\
25 \\
22 \\
18 \\
14\end{array}$ & $\begin{array}{l}45 \\
38 \\
34 \\
30 \\
27 \\
25\end{array}$ & $\begin{array}{l}62 \\
62 \\
60 \\
59 \\
46 \\
45\end{array}$ & $\begin{array}{l}74 \\
74 \\
72 \\
71 \\
63 \\
60\end{array}$ & $\begin{array}{l}79 \\
78 \\
75 \\
75 \\
66 \\
63\end{array}$ \\
\hline
\end{tabular}

Table 7. Phosphorus retention strength per Phosphorus Fertilizer Options in Tests on Autumn Wheat and Vine Crops

\begin{tabular}{|c|c|c|c|c|}
\hline $\begin{array}{l}\text { Provision of soil with } \\
\text { phosphorus }\end{array}$ & $\begin{array}{l}\text { Moving } \\
\text { Phosphorus } \\
\mathrm{P}_{2} \mathrm{O}_{5} \mathrm{mg} / 100 \mathrm{~g}\end{array}$ & $\begin{array}{l}\text { Giving } \mathrm{P}_{2} \mathrm{O}_{5} \\
\mathrm{mg} / 100 \mathrm{~g}\end{array}$ & $\begin{array}{l}\text { Absorbed } \mathrm{P}_{2} \mathrm{O}_{5} \% \text { (6 } \\
\text { month interaction) }\end{array}$ & $\begin{array}{l}\text { Harvest (one } \\
\text { hectare) }\end{array}$ \\
\hline \multicolumn{5}{|l|}{ Brown Carbonated } \\
\hline Low & 1,15 & 30 & 71,5 & 23,7 \\
\hline Medium & 4,7 & 30 & 49,7 & 42,8 \\
\hline High & 6,4 & 30 & 31,5 & 50,9 \\
\hline \multicolumn{5}{|l|}{ meadow brown } \\
\hline Low & 1,1 & 30 & 72,0 & 21,8 \\
\hline Medium & 4,6 & 30 & 50,5 & 38,1 \\
\hline High & 6,1 & 30 & 32,4 & 47,2 \\
\hline \multicolumn{5}{|l|}{ Redish } \\
\hline Low & & 30 & 73 & 3143 \\
\hline Medium & & 30 & 52 & 6770 \\
\hline High & & 30 & 35 & 7129 \\
\hline
\end{tabular}


Table 8. The table determining the quality of cultivation and the efficiency of phosphorus fertilizers (nitrogen-potassium background) according to phosphorus retention strength of the soil (reddish-brown soil with heavy texture, brown carbonate, and meadow brown soils)

\begin{tabular}{|c|c|c|c|c|c|}
\hline $\begin{array}{l}\text { Strength of } \\
\text { absorbed } \\
\text { phosphorus } \\
\text { retention \% }\end{array}$ & $\begin{array}{l}\text { Expelled } \\
\text { Phosphorus }\end{array}$ & $\begin{array}{l}\text { Grade of the } \\
\text { strength of } \\
\text { absorbed } \\
\text { phosphorus } \\
\text { retention }\end{array}$ & $\begin{array}{l}\text { Movement } \\
\text { grade }\end{array}$ & $\begin{array}{l}\text { the quality of } \\
\text { cultivation grade }\end{array}$ & $\begin{array}{l}\text { The efficiency of } \\
\text { phosphorus } \\
\text { fertilizers }\end{array}$ \\
\hline $\begin{array}{l}>70 \\
50-70 \\
30-50 \\
20-30 \\
<20\end{array}$ & $\begin{array}{l}<30 \\
30-50 \\
50-70 \\
70-80 \\
>80\end{array}$ & $\begin{array}{l}\text { Very strong; } \\
\text { strong; } \\
\text { average; } \\
\text { Weak; } \\
\text { Very weak; }\end{array}$ & $\begin{array}{l}\text { Low; } \\
\text { Weak; } \\
\text { average; } \\
\text { High } \\
\text { Very high; }\end{array}$ & $\begin{array}{l}\text { Very weak; } \\
\text { Weak; } \\
\text { average; } \\
\text { Aver. High; } \\
\text { High ; }\end{array}$ & $\begin{array}{l}\text { Weak; } \\
\text { average; } \\
\text { Good; } \\
\text { average; } \\
\text { Weak; }\end{array}$ \\
\hline
\end{tabular}

The SOUTHERN BRAZILIAN JOURNAL OF CHEMISTRY (ISSN: 2674-6891; 0104-5431) is an open-access journal since 1993. Journal DOI: 10.48141/SBJCHEM. http://www.sbjchem.com. This text was introduced in this file in 2021 for compliance reasons.

(c) The Author(s)

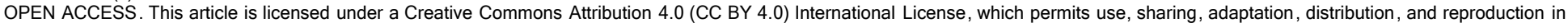

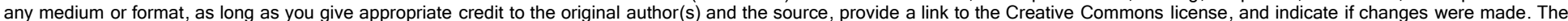

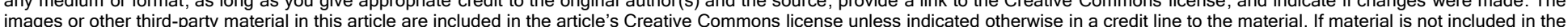

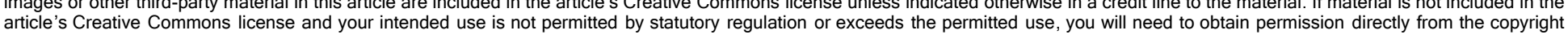
article's Creative Commons license and your intended use is not permitted by statutory
holder. To view a copy of this license, visit http://creativecommons.org/ licenses/by/4.0/. 


\title{
SOUTHERN BRAZILIAN JOURNAL OF CHEMISTRY
}

\section{BUNCH NUMBER AND ANTIOXIDANT ACTIVITY IN 'SAHEBI' AND 'HALAGHO' GRAPES AFFECTED BY PRUNING INTENSITY AND CANE LENGTH}

\author{
MAHTAB, Zonouri; DAVOOD, Bakhshi²; ESMAEIL, Fallahi ${ }^{3} ;$ ISA, Arji ${ }^{4}$ \\ ${ }^{1}$ University of Guilan, Faculty of Agricultural Sciences, University Campus 2, Department of Horticultural \\ Science. Iran
}

${ }^{2}$ University of Guilan, Faculty of Agricultural Sciences, Department of Horticultural Science. Iran

${ }^{3}$ University of Idaho, Pharma Research and Extension Center, Pharma. The USA

\begin{abstract}
${ }^{4}$ Agricultural and Natural Resources Research and Education Center, Department of Crop, and Horticultural Science Research. Iran

* Correspondence author

e-mail: Mahtab.zonouri @gmail.com
\end{abstract}

Received 12 June 2019; received in revised form 21 October 2019; accepted 21 November 2019

\begin{abstract}
Pruning methods can primarily affect grape production at various levels. Of the commonly affected features by pruning, the number of bunches has known to have a significant effect on the relation between the functions of assimilate sources and sinks. Further, fruitfulness can significantly be negatively influenced by shading. In this study, we aim to study the impact of 4,6 and 8 buds per cane with pruning intensity as light, moderate and severely pruned and their interaction in the course two consecutive years, 2017 and 2018 in 'Sahebi' and 'Halagho' (both seeded red table grape cultivars). In 2018, lightly pruned 'Halagho' and having 8 buds per cane increased number of bunches by 54.00 , which had the highest value. Results showed that there is apical buds bear more fruit by comparison to the buds with vegetative nature, 1 to 4 first buds. Based upon the outcomes of this study, it could be concluded that due to the stresses imposed by the pruning of the vines, therefore, the chemical compounds increases in order alleviate the negative aftermaths . In 2018, whole berry antioxidant activity in both cultivars was significantly lessened, and this decline was higher in 'Saahebi'. The number of bunches was increased by increasing cane length or bud load/cane. Overall, the pruning program has an impactful role in bunch number as well as antioxidant activity and in the long-run on accumulated reserves, which makes choosing and applying a specific pruning method undeniably important. Thus, emphasize the importance of further research in this field.
\end{abstract}

Keywords: Bud fertility, fruitfulness, phytochemicals, fruiting unit, nutraceutical compounds

\section{INTRODUCTION}

Table grapes are a common and chief source of phytochemical constitutes with positive effects on health (Lutz et al., 2011). Among them, colored ones are known to have the most active with multiple biological effects and potential health benefits. The antioxidants content of red grape (namely, flavonoids, anthocyanins, and tannins) found to have considerable health benefits (Haminiuk et al., 2012). Amongst grapes and even other fruits, red grape, is one of the renown fruits worldwide. However, there are some issues with red grape cultivars, V. vinifera L., namely lack of complete differentiation process for flower buds, weak coloration, as well as significant vulnerability to fungal pathogens (Wu et al., 2006). The intensity of winter pruning has a significant influence on the levels of light in the canopy (Smart et al., 1985). The absence of an appropriate degree of radiation in the clusters in the company of the high crop loads postpones the maturation process and harms the qualitative features. High altitude vineyards specially those in mountain, often located on steep, which is a common form of using those lands and are known to produce distinguishably high-quality grapes (Stanchi et al., 2013).

Viticultural methods that gardners put into practice are essential ways to regulate the plant reaction to the stressors and enhance the number of secondary chemicals, therefore, improving the quality of table grape, since these compounds are much responsible for fruit taste and antioxidant 
activity of fruit. Moreover, production control through pruning is a reliable method to enhance grapes quality (Coban and Kara, 2002). The determination of the initial number of shoots and clusters is squarely affected by pruning severity (Smart et al., 1985), and it is influences can be traced in the berry chemistry by changes in yield. The qualitative characteristics of berry and level as well as the detailed profile of polyphenolic constitutes of grapes, are commonly prone to be influenced by seasonal and weather fluctuation (De Pascali et al., 2014), abiotic and biotic stresses and canopy management (Rusjan et al., 2012).

To acquire a proper level of quality in grape production, having an adequate level of sunlight radiation is pivotal. Although there are some studies published on the antioxidant potential in grapes, the information on antioxidant activity of grape cultivars in Iran is limited. There are few works published on table grapes, whose texture attributes and chemical constituents have an essential role in determining the overall quality, and therefore the market value. Hence, here two red seeded grapevine cultivars grown in west of Iran were studied to evaluate the natural antioxidants in the stage of full ripening to determine the best pruning treatment for the production of grape with the aim of enrichment with antioxidant.

\section{MATERIALS AND METHODS}

\subsection{Site description}

The study was conducted in two consecutive growing seasons of 2017 and 2018, in a commercial vineyard located in Sarbarzeh region of Kermanshah province, in west of Iran in which two seeded red table grape cultivars, 'Sahebi' and 'Halagho' chosen from 20 year-old vines with head training at a spacing of 1.5 by $2.5 \mathrm{~m}$ in an east-west row orientation in a relatively similar status were considered. The targeted cultivars were originated from hardwood cutting and benefited from the drip irrigation system. In the course of each phenological period, the irrigation applied beside probable precipitation.

\subsection{Pruning method}

The vines considered as control were 20 years old that yearly, a moderate pruning program applied to them. In this study, our focus was investigating the possible effects of length of canes and severity of pruning. The application of the pruning program was in late - Apr in 2017 and late- Mar in 2018. Pruning intensity treatments were composed of two types of pruning; lightly pruned

Table 1. Meteorological and pedological situation

\begin{tabular}{lc}
\hline Parameters & Indices/Values \\
\hline Latitude & $34^{\circ} 45^{\prime} 46^{\prime \prime} \mathrm{N}$ \\
\hline Longitude & $47^{\circ} 11^{\prime} 34^{\prime \prime} \mathrm{E}$ \\
\hline $\begin{array}{l}\text { Elevation above } \\
\text { sea level }\end{array}$ & $1923 \mathrm{~m}$ \\
\hline Soil texture & Loam \\
\hline Soil/Water EC & $0.58 \mathrm{ds} \mathrm{\textrm {m } ^ { - 1 }}$ \\
\hline Soil/Water pH & 7.15 \\
\hline Relative humidity & $64 \%$ \\
\hline $\begin{array}{l}\text { Mean of yearly } \\
\text { precipitation }\end{array}$ & $380 \mathrm{~mm}$ \\
\hline
\end{tabular}

of the red seeded grapes vineyard in the

experimental orchard in Sarbarzeh region, Kermanshah-Iran

with the formula $40+20$ and severely pruned with $20+20$ formula (Ahmedullah and Himelrick, 1989). Then, in the number of buds per cane, substitute cane (two-node spur) were pruned with 2 bud lengths and by randomly with respective treatments: pruning, 4,6 , and 8 buds on the cane and different pruning intensity of light and intensity). To repeat this experiment in 2018, the substitute canes (two-node spur) pruned, and each on a cane, two buds remained untached.

\section{3 sampling}

Samples were obtained at the berry fully ripe stage, considering the red color appearance. Picking grape bunches was carefully randomized throughout the vines for each cultivar. Vines were well managed, uniform in size, and had no nutrient deficiency or pest damage. Each year, sampling, including two red cultivars, were harvested at their fully ripe. Plants were well managed, uniform in size, and had no nutrient deficiency or pest damage. The grape yield and its components were measured once at harvest time (Delpuech et al., 2015). Total bunches of each vine were separated and counted and were monitored at harvest during late - September in 2017 and 2018.

Fundamental juice composition analyses were performed at Guilan University, Rasht, Iran. Total antiradical capacity was extracted with DPPH (2.2-diphenyl-1-pirylhydrazyl) free radicalscavenging capacity as described by Brandwilliams (1995), scavenging capacity was estimated spectrophotometrically at $517 \mathrm{~nm}$ (T80+UV/VIS PG Instrument Ltd spectrophotometer). The DPPH solution was 
prepared daily and protected from the light. The results were expressed as a percent. Briefly, $50 \mu \mathrm{l}$ of grape extracts were mixed with $950 \mu \mathrm{LPPH}$ $0.1 \mathrm{~N}$ and kept in the dark for $30 \mathrm{~min}$ of reaction at room temperature.

The percentage inhibition of DPPH in the test sample was calculated by Equation 1:

$$
\begin{aligned}
& \% \text { Inhibition }=\left(\left(\mathrm{A}_{0} \text { control }-\mathrm{A} \text { sample }\right) / \text { control }\right) \\
& \times 100
\end{aligned}
$$

Where $A_{0}$ was the beginning absorbance at 515 $\mathrm{nm}$, obtained by measuring the same volume of solvent, and $A$ was the final absorbance of the test sample at $515 \mathrm{~nm}$ by UV-Visible spectrophotometer.

\subsection{Statistics}

The experimental design used was a splitsplit plot with three replicates. The main factors consisted of time (year) with two levels (2017 and 2018) and grape cultivars with two levels ('Sahebi' and 'Halghoo'). The severity of pruning (light, moderate, and severe) was considered as subplot factor and number of buds per cane $(4,6,8$ buds per cane) as sub-sub (or split-split) factors. Analysis of variance was performed using the SAS statistical package (version 9.4; SAS Institute, Cary, NC, USA). Differences among treatments were assessed by Duncan's range test at the level of $1 \%$ and $5 \%$.

\section{RESULTS AND DISCUSSION:}

The bunch number as an essential parameter can be influenced by several factors. In this study, the interaction between factors: years, grape cultivars, pruning severity, and the number of buds per cane showed that when 'Halagho' lightly pruned in 2018 with 8 buds per cane, the number of bunches increased significantly up to 54.00 which had the highest value. Increasing the length of cane significantly increased the cluster number (Table 1). The results in this respect are in accordance with previous studies, Abbas et al., (2008) and Gaser et al., (2017), who displayed that vines with long pruning resulted in a higher number of bunches in comparison with short pruning. Inflorescence primordia are formed by extensive branching of the anlage (Vasconcelos et al., 2009): bud fertility (number of bunches per shoot) and flower number per bunch are closely linked, as primary branching of inflorescences exerts a robust control over the total number of flowers per inflorescence (Dunn and Martin, 2007).
According to Palanichamy et al. (2004), among the three pruning treatments viz., 4, 6 and 8 buds per cane retaining uniformly 12 canes per vine in the 'heading system', the maximum number of bunches (36.2 per vine) were obtained with pruning 6 bud treatment. Kohale et al. (2013) reported in 'Sharad Seedless' that eight buds/cane level recorded the maximum number of bunches (30.68 per vine), whereas, in six buds/cane and 4 buds/cane, the number of bunches were 29.04 and 27.03 , respectively.

Numerous factors are known to affect the formation of flowers. The vegetative and reproductive growth during the current year may interact with the development of flowers for the next year, depending on the timing of floral induction. The alternate-year bearing phenomenon observed on numerous fruit tree species results from endogenous factors involved in this interaction (Wilkie et al., 2008). Other factors are directly linked with weather conditions such as temperature and light. Since the availability of carbohydrates is the determinative factor of flower induction and fruit set (Vasconcelos et al., 2009; Keller, 2015). A training system, along with pruning application, has the most substantial effect on yield due to the source/sink relationship associated with the number of buds retained during pruning (Howell, 2001). Training and pruning systems have a significant impact on yield. This impact is partly attributed to the strong association between cluster numbers per vine and cluster weight, where an increase in cluster count has been linked to a decrease in cluster weight (Gladstone and Dokoozlian, 2003, Reynolds and Heuvel 2009). Since flower buds in grapes are initiated during the previous summer, and fruitfulness of buds is determined prior to the annual pruning, the increased cluster number and plant yield seem to be owing to an increment in flower bud initiation.

Based on the level of intensity in pruning, significant amounts of the stored carbohydrates in dormant wood can be eliminated, which as a result, the shoot development process at the early season slows down. In a study conducted by Bowed and Kliewer (1990) showed that severely pruned vines develop less individual leaves on a whole vine basis in compare to non-severely pruned vines, but leaf numbers per shoot and individual leaf sizes increased. Light pruning method as another part of their study showed that generally increases yield, however, only to some extent where the vines are too large afterward fruitfulness gradually lessens. Further, in this case, the pruning severity is also under question. 
The effect of pruning intensity on yield parameters is not always stable from one year to another, as reported in a long-term four-year study carried out by Freeman et al. (1979). The fluctuation in results was vivid in which the number of clusters per shoot was had not influenced the number of clusters per shoot in a statistically significant norm (Freeman et al., 1979). In a similar study, clusters per vine almost doubled by lowering the severity of pruning from $10+10$ to $50+10$ increasing from 67 per vine to 112 per vine (Byrne and Howell, 1978).

The total antioxidant activity is a reliable measure in the evaluation of the effects of a specific pruning program. In this experiment the antioxidant activity affected by different interaction of the factors years, grape cultivars, pruning severity and the number of buds per cane, from which the lightly pruned 'Halaghoo' in 2017 and maintenance of 4 or 8 buds per cane enhanced the total antioxidant activity in the whole berry. Also, values in comparison with control treatment in 2017 were not statistically significantly difference. In other treatments, total antioxidant activity in the whole berry decreased significantly. In 2018, whole berry antioxidant activity in both cultivars was significantly decreased, which this decline was higher in 'Saahebi' compared to 'Halaghoo' (Table 5).

Grapes are long known to be a distinguishable source of antioxidant compounds, such as polyphenols. The polyphenols are able to squarely act as antioxidants or to affect the biosynthesis of other antioxidants constitutes, in the body. (Sato et al., 2000; Wolpert et al., 1980). The natural features of grapes also significantly contribute to their phytochemical potentials, for example, color-skinned grapes aggregate high amount of anthocyanins in their skins, while such ability is absence in whiteskinned varieties. In a study, the polyphenol level of black- and red-skinned cultivars were statistically higher than white-skinned cultivars. (Shiraishi et al., 2018).

The correlation between high total phenolic contents and high antioxidant activities has been reported in various grape cultivars (Meyer et al., 1997). The present study reveals a strong correlation between total antioxidant activity and total phenolics $\left(R^{2}=0.9829, p<0.05\right)$. Kanner et al. (1994) found a correspondence pattern between the antioxidant activity of grape varieties and the concentration of phenolics in a number of different systems.

The variation in antioxidant activity of various parts of berry has been well-documented, in which Xu et al. (2010) conducted a comparative study on that the antioxidant profiles of 18 Chinese grape cultivars with to European grapes and Muscadine grapes. Among them, V. vinifera "Cabernet Sauvignon" and Muscadine grapes had the highest amount of phenolic compounds and antioxidant properties in seed, while the Oriental Vitis species "Black Pearl" and "Sangye" were found to be the richest in phenolic contents in the skin. Variations in the number of growing fruits not only have a direct effect on yield but may have undesirable effects on the size and quality of harvested organs (Kliewer and Dokoozlian, 2005). The effects of training systems on grape quality were investigated in relation to a particular training system since it affects the light interception (Smart, 1984) and the microclimate inside the canopy and around the clusters (Gladstone and Dokoozlian, 2003). Pruning method can be useful on other phytochemicals such as anthocyanin level, for instance, Zonouri et al. (2019) reported that severity of pruning significantly increased the anthocyanin of berry majorly due to imposing a stress condition as result of intense pruning.

\section{CONCLUSIONS:}

Obviously, numerous studies are required to unmask the underlining patterns affected by pruning procedure and influences the qualitative characteristics of the grape. To fill the information gape in this case, the impact of pruning severity was evaluated on two Iranian red grape cultivars 'Saahebi' and 'Halaghoo'. Which lightly pruning method in 'Halaghoo' happened to have the highest number of bunches in the second year. While the same cultivar due to experiencing stress conditions in the first year even under lightly pruned conditions had highest amount of antioxidant activity. The practical knowledge that this study provides could be applied by viticulturists in order to have suitable and optimized pruning program. However, there a lot more need to be discovered, specially the effect of similar pruning procedure on chemical profile of grapes at the biosynthetic level or establishing long-term experiments to find behavioral patterns.

\section{ACKNOWLEDGMENTS:}

We thank the Department of Horticultural Sciences of the University of Guilan for supplying equipment to this study.

\section{REFERENCES:}

1. Abbas, E., Hanaa, S., El-Helw, A., Abd El- 
Wahab, M. A., Hassan, F. F. J. Agric. Sci. Mansoura Univ, 2008, 33 (8), 5655 - 5668.

2. Ahmedullah, M., Himelric. D. C. Grape. Manage, 1989, 383-471.

3. Bowed, P. A., Kliewer. W. M. J. Amer. Soc. Hort. Sci, 1990, 115 (4), 530-534.

4. Brand-Williams, W., Cuvelier, M. E., Berset, C. LWT-Food. Sci. Tech, 1995, 28(1), 25-30.

5. Byrne, M. E., Howell. G. S. Am. J. Enol. Vitic, 1978, 29(3), 192-198.

6. Coban, H. Kara, S. Asian. J. Sci, 2002, 1: 414-416.

7. De Pascali, S. A., Coletta., A., Del Coco., L., Basile., T., Gambacorta., G., Fanizzi. F. P. Food. Chem, 2014, 161, 112-119.

8. Dunn, G., Martin. S. Aust. J. Grape. Wine. Res, 2007, 13, 95-100.

9. Freeman, B. M., Lee, T. H., Turkington. R. Am. J. Enol. Vitic, 1979, 30 (3), 218-223.

10. Gaser, A. S. A., Abd El-Wahab M. A. Abd El-Wadoud, M. Z. Egypt. J. Appl. Sci, 2017, 32(4), 101-120.

11. Delpuech, X., Gontier, L., Cahurel, J., Dufourcq, T., Payan, J. 2015. Retrieved from https://www.vignevin.com/wpcontent/uploads/2019/03/Giesco2015.pdf

12. Gladstone, E. A. Dokoozlian. N. K. Vitis, 2003, 42,123-131.

13. Haminiuk, C. W. I., Maciel, G. M., PlataOviedo, M. S. V., Peralta. R. M. Int. J. Food Sci. Tech, 2012, 47, 2023-2044.

14. Howell, G. Amer. J. Enol. Viti, 2001, 52, 165-174.

15. Kanner, J., Frankel, E. N., Granit, R., German, B., Kinsella. E. J. Agric. Food Chem, 1994, 42, 64-69.

16. Keller, M. 2nd edition, Elsevier Academic Press, London, 2015.

17. Kliewer, W. M., Dokoozlian. N. K. Amer. J. Enol. Vitic, 2005, 56, 170-181.

18. Kohale, V. S., Kulkarni, S. S., Ranpise, S. A., Garad. B. V. Bioinfolet, 2013, 10(1B), 300-302.

19. Lutz, M., Jorquera, K., Cancino, B., Ruby, R., Henriquez. C. J. Food. Sci, 2011, 76, 1088-1093.

20. Meyer, A. S., Yi, O. S., Pearson, D. A., Waterhouse, A. L., Frankel. E. N. J. Agric. Food. Chem, 1997, 45 (5): 1638-1643.

21. Palanichamy, V., Jindal, P. C., Singh. R. Agric. Sci. Dig, 2004, 24 (2), 145-147.

22. Reynolds, A. G., Vanden Heuvel. V. J. Amer. J. Enol. Vitic, 2009, 60, 251-268.

23. Rusjan, D., Veberic, R., Mikulic-Petkovsek, M. Eur. J. Plant Path, 2012, 133, 965-974.
Hirakawa. N. Sci. Hortic, 2000, 85: 75-83.

25. Shiraishi, M., Shinomiya, R., Chijiwa. H. Sci Hortic, 2018, 227, 272-277.

26. Smart, R. E. Amer. J. Enol. Vitic, 1985, 35, 230- 932.

27. Smart, R. E., Robinson, J. B., Due, G. R., Brien. C. J. Vitis, 1985, 24, 17-31.

28. Smart, R. E. Aust wine. Indust. Tech. conf, 1984, 113-132.

29. Stanchi, S., Godone, D., Belmonte, S., Freppaz, M., Galliani, C., Zanini, E. J. Maps, 2013, 9, 367-372.

30. Vasconcelos, M. C., Greven, M., Winefield C. S., Trought M. C. Raw. V. Amer. J. Enol. Viti, 2009, 60(4), 411-434.

31. Wilkie, J. D., Sedgley, M. Olesen. T. J. Expe. Bot, 2008, 59 (12), 3215-3228.

32. Wolpert, J. A., Howell, G. S., Cress. C. E. J. Amer. Soc. Hortic. Sci, 1980, 105, 434438.

33. Wu, J., Cheng, J., Xie, M., Wang, H., Chen, J., Yang. Z. J. Fruit. Sci, 2006, 23, 191195.

34. Xu, W., Yu, Y., Ding, J., Hua, Z., Wang. Y. Planta, 2010, 231,475-487.

35. Xu, C., Zhang, Y., Cao, L., Lu. J. Food. Chem, 2010, 119, 1557-1565.

36. Zonouri; M., Bakhshi; D., Fallahi; E., Arji, I. Periodico, Tche. Quimica, 2019.

The SOUTHERN BRAZILIAN JOURNAL OF CHEMISTRY (ISSN: 2674-6891; 0104-5431) is an open-access journal since 1993. Journal DOI: 10.48141/

SBJCHEM. http://www.sbjchem.com. This text was introduced in this file in 2021 for compliance reasons.

(c) The Author(s)

OPEN ACCESS. This article is licensed under a Creative Commons Attribution 4.0 (CC BY 4.0) International License, which permits use, sharing, adaptation, distribution, and reproduction in any medium or format, as long as you give appropriate credit to the original author(s) and the source, provide a link to the Creative Commons license, and indicate if changes were made. The images or other third-party material in this article are included in the article's Creative Commons license unless indicated otherwise in a credit line to the material. If material is not included in the article's Creative Commons license o view a copy of this license, visit http://creativecommons.org/licenses/by/4.0/. 


\title{
SOUTHERN BRAZILIAN JOURNAL OF CHEMISTRY
}

\section{INDICATORS OF TRYPSIN-LIKE ACTIVITY OF MIXED SALIVAAFTER INSTALLING THE ENDOSSEOUS IMPLANTS IN THE PRESENCE OF GASTRIC ULCER AND DUODENAL ULCER}

\author{
KUZNETSOVA, Mariya*, NIKONOVA, Anna; KUZNETSOV, Ivan; SEVBITOVA, Mariya; \\ TIMOSHINA, Mariya \\ Department of Propaedeutic of Dental Diseases of I. M. Sechenov First Moscow State Medical University \\ (Sechenov University) \\ * Correspondence author \\ e-mail: mary-smith@yandex.ru
}

Received 22 August 2019; received in revised form 30 October 2019; accepted 21 November 2019

\begin{abstract}
The trypsin-like activity of mixed saliva in orthopedic patients after implant placement was monitored. Proved negative impact on the processes of repair of background somatic pathology (peptic ulcers and 12 duodenal ulcers), justify the application of immunomodulator "Erbisol" as a drug that speeds up the repair processes during implantation. At present, the relevant issues are those related to the development of inflammatory complications at the stage of rehabilitation of patients, especially in the presence of somatic pathology and the study of the tissue complex of the implantation zone. Peptic ulcer disease occupies one of the main places in the structure of lesions of the digestive system. The close interdependence between the pathology of internal organs and the oral cavity is confirmed by numerous observations and studies. Implant placement is accompanied by changes in the enzymatic activity of mixed saliva. The presence of somatic pathology (ulcerative disease of the stomach and 12 duodenal ulcers) often leads to more long-term violations of the enzymatic activity of saliva. The use of the drug "Erbisol" in orthopedic dentistry accelerates the repair process, as evidenced by the earlier periods of normalization of the enzymatic activity of mixed saliva, after the installation of implants.Regular and timely monitoring of the condition of the periarticular tissues, as well as objective diagnosis of early inflammatory complications, are necessary to ensure the reliability and long-term functioning of prosthetic structures installed on implants in the oral cavity. It can be concluded that the purpose of our study was to study the trypsin-like activity (TPA) of mixed saliva after implant placement on the background of somatic pathology.
\end{abstract}

Keywords: trypsin-like activity mixed saliva implants. 


\section{INTRODUCTION}

Dental implantology is a
multidisciplinary specialty. Due to its
knowledge intensity and integrative potential, it
is experiencing rapid development. Treatment
of patients with the use of implants is of great
interest to both specialists and a large number
of patients.

Over the past three decades, this type of treatment has been successfully used in many countries of the world. In Russia, dental implantology began to develop somewhat later than in other countries, however, at the state level solved many problems that contribute to the successful development of this section of dentistry.

The use of dental implants in dental practice has allowed a qualitatively new level to solve the problem of orthopedic treatment of patients with dentition defects (Matsui, 2015; David Y. Graham, 2014; Bonet-Costa, 2019; Kumar, 2019; Aviñó, 2019; Berryman, 2019).

In the practice of dental implantology, the issues related to the study of the tissue complex of the implantation zone and the development of inflammatory complications at the stage of rehabilitation of patients, especially in the presence of somatic pathology, are still relevant (Cleaver, 2019; Mangine, 2019; Pitchford, 2019; Yanushevish, 2019). In the structure of lesions of the digestive system, one of the main places is occupied by peptic ulcers. Numerous observations and studies have confirmed the close interdependence between the pathology of internal organs and the oral cavity and the need for a broad General clinical approach to the study of these diseases (Liu, 2019; Preau, 2019; Gao, 2019; Voloshina, 2018).

To ensure the reliability and long-term functioning of prosthetic structures installed on implants in the oral cavity, it is necessary to regularly and timely monitor the state of the near-implant tissues, as well as objective diagnosis of early inflammatory complications (Sourabh, 2019; Petrovic, 2019; RoldánPadrón, 2019; Evstratenko, 2018).

Orthopedic treatment was carried out using a two-stage procedure of implant endosseous screw implants U-Impl. When using collapsible (two-stage) implants by a one- stage method, it is desirable that their configuration provides for a smooth cylindrical neck with a height of 1.5-2.0 mm, (for implants with an internal connection). The implant is installed so that the orthopedic platform rises above the level of the bone ridge by $1.5-2.0 \mathrm{~mm}$ or more. When using two-stage implants, if there are conditions for immediate loading, it is desirable to install permanent abutments, especially in aesthetically important areas. Two-stage implantation involves the installation of all elements of the implant structure in stages. At the first stage, the intraosseous element is installed. After the implant is placed, a mucosal flap is sutured over it. Passes closed engraftment of the implant (not communicating with the oral cavity).

Closed engraftment is: without load (when the implant is located below the top of the alveolar ridge or at the level of the alveolar ridge), with load (when the implant is located above the top of the alveolar ridge). The period of engraftment of two-stage implants on the upper jaw is 4-6 months, on the lower jaw is 23 months.

The studies were carried out on the spectrophotometer DR-3900 (HACH-LANGE, Germany) (Figure. 1), which allows you to keep under control the entire measurement process, from sampling and ending with the preservation of the result.

The powerful system of registration of samples and operators is complemented by the technology of wireless tags - RFID (radio frequency identification).

The packaging of the test cells also receives an RFID tag containing information about the measurement process and shelf life. When changing the measurement process, the device considers the information on its own (Sevbitov, 2019; Kuznetsova, 2019; Shchetinin, 2019); .

The measurement results are easy to read on the large color touch screen. An intelligent sample and user accounting system allows you to monitor the sample analysis process.

The device is equipped with quality control programs AQA + analysis. At any time, the user can check the correctness of the results, the accuracy of the pipette, the correct dilution. Current batch certificates (to document GMP/GLP results) are located in the RFID tag 
on the cuvette package. The RFID technology allows you to instantly display the DR 3900 and print all the information on a particular batch.

Based on the above, the aim of our study was to study the trypsin-like activity (TPA) of mixed saliva after implant placement on the background of somatic pathology (Tsakiri, 2019; Zhong, 2019; Tsalikis, 2019; Magnen, 2019; Greenwood, 2019).

\section{MATERIALS AND METHODS}

All research methods under this article have been conducted in accordance with the relevant guidelines and regulations. The quality of scientific research is achieved by observing the principles. The component of the purposefulness-the study is carried out in accordance with the objectives of improving the practice of education, the approval of the relations of humanity in it. The component of objectivity-theoretical models in the study should reflect the real pedagogical objects and processes in their multidimensionality and diversity. The component of applied orientation-the results of the study should contribute to the explanation, prediction, and improvement of educational practice in a plurality of ways of its development. The component of consistency-the results of the study are included in the system of scientific knowledge, Supplement the available information with new information. The component of integrity-the components of an educational object is studied in the dynamics of a multidimensional picture of their relationships and interdependencies. The component of dynamism-reveals the patterns of formation and development of the studied educational facilities, the objective nature of their multidimensional and multivariate. These principles are based on the laws of cognitive activity, scientific research and the specifics of educational practice. All experimental protocols were approved by the Local Ethics Committee of I. M. Sechenov First Moscow State Medical University (Sechenov University). Prior to the study, informed consent was obtained from all patients for the upcoming study.

The material of this study was the mixed saliva of patients who underwent dental implantation. Orthopedic treatment was performed using a two-stage method of implantation with U-Impl screw endossal implants (Figure. 2). U-Impl implants are made of titanium class $5-$ material with maximum bioinert, the risk of rejection of such implants is minimized, their installation is shown even to allergies. The low weight allows patients to feel these implants as their own teeth - they do not give excessive load on the jaw, and the habituation to them passes quickly and imperceptibly. The surface of the titanium pin implanted into the bone has a porous hydrophilic structure-so that the process of osseointegration is accelerated and takes place more fully. The specific structure of the implant allows the bone substance to hold it more tightly - the degree of fixation is higher than the average. At the point of contact with the abutment implant due to the smoothness of these surfaces is not formed plaque that can provoke inflammation. The special design of the abutment ensures uniform load distribution over the entire area of the implant-the risk of displacements or formation of microcracks is reduced to zero. U-Implant Simpl Swiss dental implants can be used in all cases of dental practice: they are optimally suited for one-stage and two-stage implantation with a preliminary stage of bone augmentation. In both cases, the rate of full survival-one of the highest among modern implant systems. For the study, 87 patients (37 women and 50 men) aged $21-64$ years were examined. Selecting patients, the General condition of an organism, the transferred and accompanying diseases, an anatomical and physiological condition of an oral cavity were considered.

The patients were divided into 3 groups: the 1st group included orthopedic patients without somatic pathology-20 patients; the 2nd group - orthopedic patients with somatic pathology (gastric ulcer and duodenal ulcer) 27 patients; group 3 consisted of 25 patients in need of orthopedic care and having background somatic pathology, who were administered $1 \mathrm{ml}$ of the immunomodulator Erbisol intramuscularly every other day during the first 30 days after implantation.

In addition, 15 practically healthy persons (norm) not suffering from dental pathology were examined - the control group. The orthopedic treatment was carried out using a two-stage procedure of implant endosseous screw implants U-Impl. The study used the drug "Erbisol" - immunomodulator, drug, adaptogen. Erbisol is a complex of natural nonprotein low molecular weight organic compounds of non-hormonal origin, derived from animal embryonic tissue, containing 
glycopeptides, peptides, nucleotides, amino acids in a solution of $0.9 \%$ isotonic sodium chloride; dry residue 11-17 mg-/-ml.

This drug contains low-molecular signal fragments of membrane glycoproteins that function as markers of the physiological state of cells, which in pathological disorders of homeostasis activate the immune system. Erbisol drugs affect only unbalanced systems, affected organs, and tissues and remain virtually indifferent to a healthy body, without causing adverse reactions.

Trypsin-like activity (TPA) of mixed saliva in patients was measured by a spectrophotometric DR 3900 method based on the change in the rate of cleavage of $\mathrm{N}$ benzene - L-arginine from the synthetic substrate n-benzene - L-arginine ethyl alcohol (Reanal).

For its implementation, $0.5 \mathrm{ml}$ of saliva was diluted to $2 \mathrm{ml}$ of $0.05 \mathrm{M}$ Tris-HCL buffer ( $\mathrm{pH}-8.0)$, and after a preincubation period of 5 minutes, $1 \mathrm{ml}$ of BAEE (benzoyl-arginine-ethyl ether) solution was added. The reaction was carried out in a thermostatic cuvette $\left(250{ }^{\circ} \mathrm{C}\right)$ spectrophotometer, registering an increase in optical density at $253 \mathrm{~nm}$ at intervals of 5 minutes for 30 minutes against the control sample for spontaneous hydrolysis of BAEE. The activity was calculated by the formula:

$\mathrm{TLA}=\Delta \mathrm{D} 253^{30} \times 3 /(1.1 \times 0.5 \times 30)-\Delta \mathrm{D} 253^{30}$ $\mu \mathrm{mol} / \mathrm{ml}$, where:

- $\triangle \mathrm{D} 253^{30}$ is the increase of optical density in 1 $\mathrm{ml}$ of the sample at $253 \mathrm{~nm}$ within 30 minutes;

- 3 - sample volume $(\mathrm{ml})$;

- 0.5 - the amount of saliva taken for analysis (ml);

- 1.1 - the increase in optical density at 253

$\mathrm{nm}$, corresponding to the formation of $1 \mu \mathrm{mol}$

BAEE in $1 \mathrm{ml}$ of the sample;

- 30 - reaction time $(\mathrm{min})$.

The results were expressed in micromoles of the hydrolyzed substrate in $1 \mathrm{ml}$ per minute. All the obtained digital material was processed by the method of variation statistics with the derivation of the student's criterion, and the indicators were considered reliable at $p<$ 0.05 .

\section{RESULTS AND DISCUSSION:}

By 1 month after the implant placement, all three study groups showed a statistically significant $(p<0.05)$ increase (TPA) in the mixed saliva (Diagram. 1), which was apparently a reaction of periodontal tissues to the implantation (Table. 1).

In the subsequent terms after the implant placement, by 3 months, there was a cascade and statistically significant $(p<0.05-$ 0.01 ) increase in trypsin-like activity of the mixed saliva in all studied groups of patients, but the most manifest changes were observed in group 2 (orthopedic patients with gastric ulcer and duodenal ulcer), where the TPA of the mixed saliva was $61.86 \pm 1.62 \mu \mathrm{mol} / \mathrm{ml} \times \mathrm{min}$, which was $29.1 \%(p<0.01)$ higher than control groups indicators (Diagram. 2). In the next 6 months after the implantation in the patients of the groups 1 and 3 of observations stabilization and some decrease of enzymatic activity of the mixed saliva which by this term acquired in relation to control unreliable character $(p>0,05)$ was noted (Diagram. 3).

At the same time, in the orthopedic patients with somatic pathology, TPA, despite some decrease remained at a high level and amounted to $55.78 \pm 1.44 \mu \mathrm{mol} / /-\mathrm{ml} \cdot \mathrm{min}$, which was $16.4 \%(p<0.05)$ higher than the control parameters. In the following (long-term followup of 12 months), the trypsin-like activity of mixed saliva in all three study groups approached the control parameters, acquiring a statistically insignificant character in relation to them ( $p>0.05$ ) (Diagram. 4).

\section{CONCLUSIONS:}

It can be concluded that the implant placement is accompanied by changes in the enzymatic activity of mixed saliva. The presence of somatic pathology (gastric ulcer and 12 duodenal ulcers) leads to more prolonged violations of the enzymatic activity of the saliva. The use of the drug "Erbisol" in orthopedic dentistry accelerates the repair process, as evidenced by the earlier periods of normalization of the enzymatic activity of mixed saliva, after the installation of implants.

\section{ACKNOWLEDGMENTS:}

This work was done at Sechenov University with supported by the "Russian Academic Excellence Project 5-100". 


\section{REFERENCES:}

1. Aviñó A., Jorge A., Huertas C., Pais A., Lechuga L., Eritja R., Fabrega C. Aptamerpeptide conjugates as a new strategy to modulate human a-thrombin binding affinity. Biochim Biophys Acta Gen Subj, 2019, 1863(10), 1619-1630.

2. Berniger Romariz J., Nonnemacher C., Abreu M., Dickel Segabinazi J., Bandeira J., Beltran G., Souza A., Torres I., Caumo W. The Fear of Pain Questionnaire: psychometric properties of a Brazilian version for adolescents and its relationship with brain-derived neurotrophic factor (BDNF). J Pain Res, 2019, $12,2487-2502$.

3. Berryman K., Buhimschi C., Zhao G., Axe M., Locke M., Buhimschi I.. Proteasome Levels and Activity in Pregnancies Complicated by Severe Preeclampsia and Hemolysis, Elevated Liver Enzymes, and Thrombocytopenia (HELLP) Syndrome. Hypertension, 2019, 73(6), 1308-1318.

4. Bonet-Costa V., Sun P., Davies K. Measuring redox effects on the activities of intracellular proteases such as the 205 Proteasome and the Immuno-Proteasome with fluorogenic peptides. Free Radic Biol Med, 2019, 143, 16-24.

5. Caguazango J., Pazos Á. Microbiota, according to gastric topography in patients with a low or high risk of gastric cancer in Nariño, Colombia Biomedica, 2019, 39(2), 157-171.

6. Cleaver L., Moazzez R., Carpenter G. Mixed aerobic-anaerobic incubation conditions induce proteolytic activity from in vitro salivary biofilms. J Oral Microbiol, 2019, 11(1), 164-172.

7. Daikoku T., Okuda T., Kawai M., Morita N., Tanaka T., Takemoto M., Fukuda Y., Takahashi K., Nomura N., Shiraki K. Growth activation of influenza virus by trypsin and effect of T-705 (favipiravir) on trypsin-optimized growth condition. Acta Virol, 2019, 63(3), 309315.

8. Gao X., Xu Y., Cai Y., Shi J., Chen F., Lin Z., Chen T., Xia Y., Shi W., Zhao Z. Effects of filtered fresh air ventilation on classroom indoor air and biomarkers in saliva and nasal samples: A randomized crossover intervention study in preschool children. Environ Res, 2019, 179, 108-112.

9. Goettig P., Brandstetter H., Magdolen V. Surface loops of trypsin-like serine proteases as determinants of function. Biochimie, 2019, S0300-9084(19), 30262-7.

10. Greenwood E., Rayner J., Hughes P. Mixing Sows into Alternative Lactation Housing Affects Sow Aggression at Mixing, Future Reproduction, and Piglet Injury, with Marked Differences between Multisuckle and Sow Separation Systems. Animals (Basel), 2019, 9(9), 658-665.

11. Jordanishvili A. Oral liquid adult: age peculiarities of the physicochemical properties and micro crystallization. Adv Gerontol, 2019, 32(3), 477-482.

12. Karthik P, Ettelaie R, Chen J. Oral behaviour of emulsions stabilized by mixed monolayer. Food Res Int, 2019, 125, 108-113.

13. Kumar B., Verma S., Kashif M., Sharma R., Dixit R., Singh A., Pande V., Saxena A., Abid M., Pandey K. Metacaspase-3 of Plasmodium falciparum: An atypical trypsinlike serine protease. Int J Biol Macromol, 2019, $138,309-320$.

14. Liu H., Liu Y., Song C., Ning J., Cui Z. Functional characterization of two clip-domain serine proteases in the swimming crab Portunus trituberculatus. Fish Shellfish Immunol, 2019, 89, 98-107.

15. Magnen M., Gueugnon F., Petit-Courty A., Baranek T., Sizaret D., Brewah Y., Humbles A., Si-Tahar M., Courty Y. Tissue kallikrein regulates alveolar macrophage apoptosis early in influenza virus infection. Am J Physiol Lung Cell Mol Physiol, 2019, 316(6), 1127-1140.

16. Mangine G., Kliszczewicz B., Boone J., Williamson-Reisdorph C., Bechke E. PreAnticipatory Anxiety and Autonomic Nervous System Response to Two Unique Fitness Competition Workouts. The Sports (Basel), 2019, 7(9), 199-206.

17. Matsui S., Kashida H., Asakuma Y., Sakurai T., Kudo M. Nihon Rinsho. Gastric ulcer, duodenal ulcer, 2015, 73(7), 1116-22. 
18. Petrovic I., Ahmed Z., Matros E., Huryn J., Shah J., Rosen E. Endosseous (dental) implants in an oncologic population: a primer for treatment considerations. Quintessence Int, 2019, 50(1), 40-48.

19. Pitchford E., Hasson R., Hornyak J., Lumeng J., Peterson K., Ulrich D. Diurnal cortisol and obesity in adolescents with and without Down syndrome. J Intellect Disabil Res, 2019, 205-211.

20. Preau S., Ambler M., Sigurta A., Kleyman A., Dyson A., Hill N., Boulanger E., Singer M. Protein recycling and limb muscle recovery after critical illness in slow- and fasttwitch limb muscle. Am J Physiol Regul Integr Comp Physiol, 2019, 316(5), 584-593.

21. Riis J., Granger D., Woo H., Voegtline K., DiPietro J., Johnson S. Long-Term Associations Between Prenatal Maternal Cortisol and Child Neuroendocrine-Immune Regulation. Int J Behav Med, 2019 10-17.

22. Roldán-Padrón O., Castro-Guillén J., García-Arredondo J., Cruz-Pérez M., DíazPeña L., Saldaña C., Blanco-Labra A., GarcíaGasca T. Snake Venom Hemotoxic Enzymes: Biochemical Comparison between Crotalus Species from Central Mexico. Molecules, 2019, 24(8), 1489.

23. Shin H., Baek D., Lee S. Inhibitory effect of Lactococcus lactis on the bioactivity of periodontopathogens. J Gen Appl Microbiol, 2018, 64(2), 55-61.

24. Sourabh S., Sharma N., Sharma R., Kumar R., Thakur S., Bodh V., Sharma B. Clinical Profile, Severity and Outcome of Acute Upper Gastrointestinal Bleeding in Elderly Patients Compared to Non-elderly Patients: A Prospective Observational Study. J Assoc Physicians India, 2019, 67(9), 30-32.

25. Souto X., Branquinha M., Santos A. Chymotrypsin- and trypsin-like activities secreted by the multidrug-resistant yeasts forming the Candida haemulonii complex. An Acad Bras Cienc, 2019, 91(3), 195-202.

26. Tsakiri E., Gumeni S., Vougas K., Pendin D., Papassideri I., Daga A., Gorgoulis V., Juhász G., Scorrano L. Proteasome dysfunction induces excessive proteome instability and loss of mitostasis that can be mitigated by enhancing mitochondrial fusion or autophagy. Autophagy, 2019, 15(10), 17571773.

27. Tsalikis J., Abdel-Nour M., Farahvash A., Sorbara M., Poon S., Philpott D., Girardin S. Isoginkgetin, a Natural Biflavonoid Proteasome Inhibitor, Sensitizes Cancer Cells to Apoptosis via Disruption of Lysosomal Homeostasis and Impaired Protein Clearance. Mol Cell Biol, 2019, 39(10). 489-18.

28. Yanushevish O., Dukhovskaya $H_{\text {., }}$ Ostrovskaya I., Vavilova T., Akhmedov G., Novikova T., Shashkovskaya B., Spiridonova $V$. Study of the quantity of interleukin- 6 by SDSPAAG electrophoresis and immuno-enzyme analysis in mixed saliva after rinsing the oral cavity with oligonucleotide specific. Klin Lab Diagn, 2019, 64(7), 413-416.

29. Zhong Y., Xu G., Huang S., Zhao L., Zeng Y., Xiao X., An J., Liu J., Yang T. Celastrol induce apoptosis of human multiple myeloma cells involving inhibition of proteasome activity. Eur J Pharmacol, 2019, 853, 184-192.

30. Voloshina, I. M., Borisov, V. V., Sevbitov, A.V., Davidyants, A.A., Mironov, S. N., Kuznetsova, M. Yu., Ergesheva, E. V. Distinctive features of microcrystallization of mixed saliva in children with different levels of activity of carious process. Asian Journal of Pharmaceutics, 2018, 12(S3), 1017-1020.

31. Evstratenko, V. V., Sevbitov, A. V., Platonova, V. V., Selifanova, E. I., Dorofeev, A. E. The characteristics of crystallization of mixed saliva in patients using heroin and methadone. Klinichescheskaya Laboratornaya Diagnostika, 2018, 63(4), 223-227.

32. Sevbitov, A.V., Dorofeev, A.E., Kuznetsova, M.Yu., Timoshin A.V., Ershov, K.A. Comparative characteristics of the crystallogram of the oral fluid in patients who use heroin and methadone. Periódico tchê química, 2019, 16(33), 94-101.

33. Kuznetsova, M.Yu., Mitin, N.E., Davidyants, A.A., Kalinovskii, S.I., Kuznetsov, I.I. Comparative characteristics of gingival fluid sampling methods for evaluation of orthodontic treatment results. Medical and pharmaceutical journal "Pulse", 2019, 21(7), 37-41. 
34. Shchetinin, E.V., Sirak, S.V., Petrosyan, G.G., Kochkarova, Z.M., Andreev, A.A., Garus, Y.N. Estimation of mechanisms of bone tissue mineralization in different stages of reparative osteogenesis in the conditions of ultrafonophoresis. Medical News of North Caucasus, 2019, 14(1), 260-264.

Table 1. Trypsin-like indicators of mixed saliva in orthopedic patients after implant placement on the background of gastric ulcer and duodenal ulcer ( $\mu \mathrm{mol} / \mathrm{ml} \times \mathrm{min})$.

\begin{tabular}{|c|c|c|c|c|}
\hline \multirow{2}{*}{$\begin{array}{c}\text { Observation } \\
\text { group }\end{array}$} & \multicolumn{4}{|c|}{ Observation period (months) } \\
\hline & 1 & 3 & 6 & 12 \\
\hline $\begin{array}{l}\text { Group 1- } \\
\text { Orthopedic } \\
\text { patients without } \\
\text { somatic } \\
\text { pathology } n=20\end{array}$ & $\begin{array}{c}55,84 \pm 1,56 \\
p<0,05\end{array}$ & $\begin{array}{c}57,34 \pm 1,62 \\
p<0,05\end{array}$ & $\begin{array}{c}52,24 \pm 1,74 \\
p>0,05\end{array}$ & $\begin{array}{c}49,15 \pm 1,49 \\
p>0,05\end{array}$ \\
\hline $\begin{array}{l}\text { Group 2- } \\
\text { Orthopedic } \\
\text { patients with } \\
\text { somatic } \\
\text { pathology } n=27\end{array}$ & $\begin{array}{c}56,07 \pm 1,58 \\
p<0,05\end{array}$ & $\begin{array}{c}51,86 \pm 1,62 \\
p<0,05\end{array}$ & $\begin{array}{c}55,78 \pm 1,44 \\
p<0,05\end{array}$ & $\begin{array}{c}52,77 \pm 1,35 \\
p>0,05\end{array}$ \\
\hline $\begin{array}{c}\text { Group 3- } \\
\text { Orthopedic } \\
\text { patients with } \\
\text { somatic } \\
\text { pathology using } \\
\text { «Erbisol» } n=25\end{array}$ & $\begin{array}{c}55,93 \pm 1,64 \\
p<0,05\end{array}$ & $\begin{array}{c}58,12 \pm 1,82 \\
p<0,05\end{array}$ & $\begin{array}{c}53,81 \pm 1,44 \\
p>0,05\end{array}$ & $\begin{array}{c}50,08 \pm 1,82 \\
p>0,05\end{array}$ \\
\hline $\begin{array}{c}\text { Control (healthy) } \\
n=15\end{array}$ & $47,90 \pm 1,55$ & & & \\
\hline
\end{tabular}

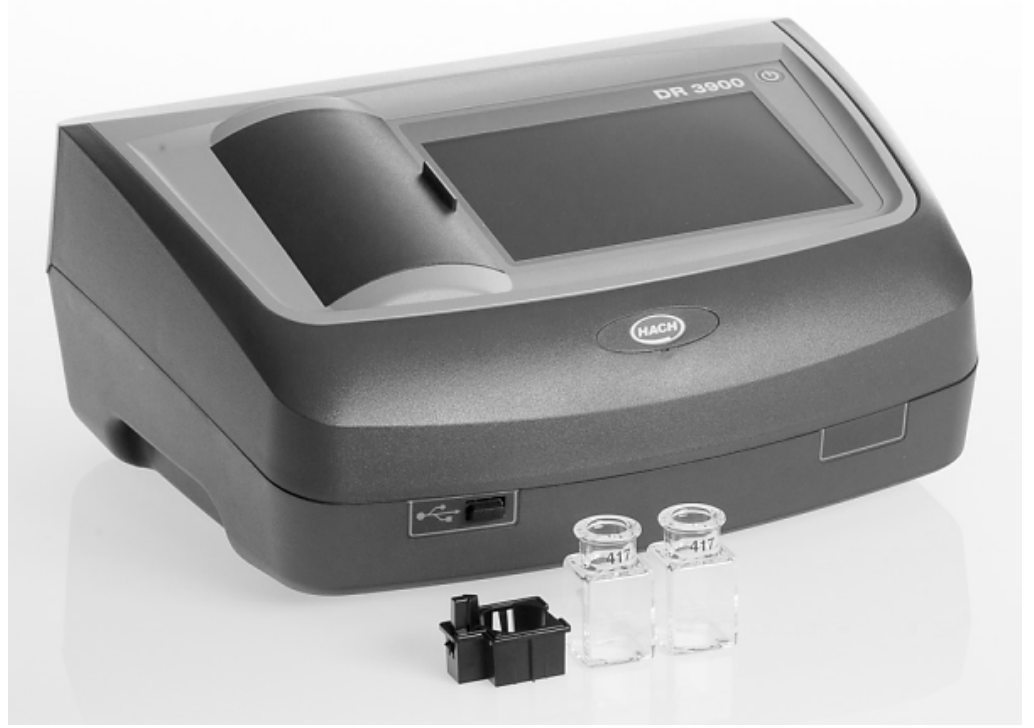

Figure 1. Spectrophotometer DR-3900 


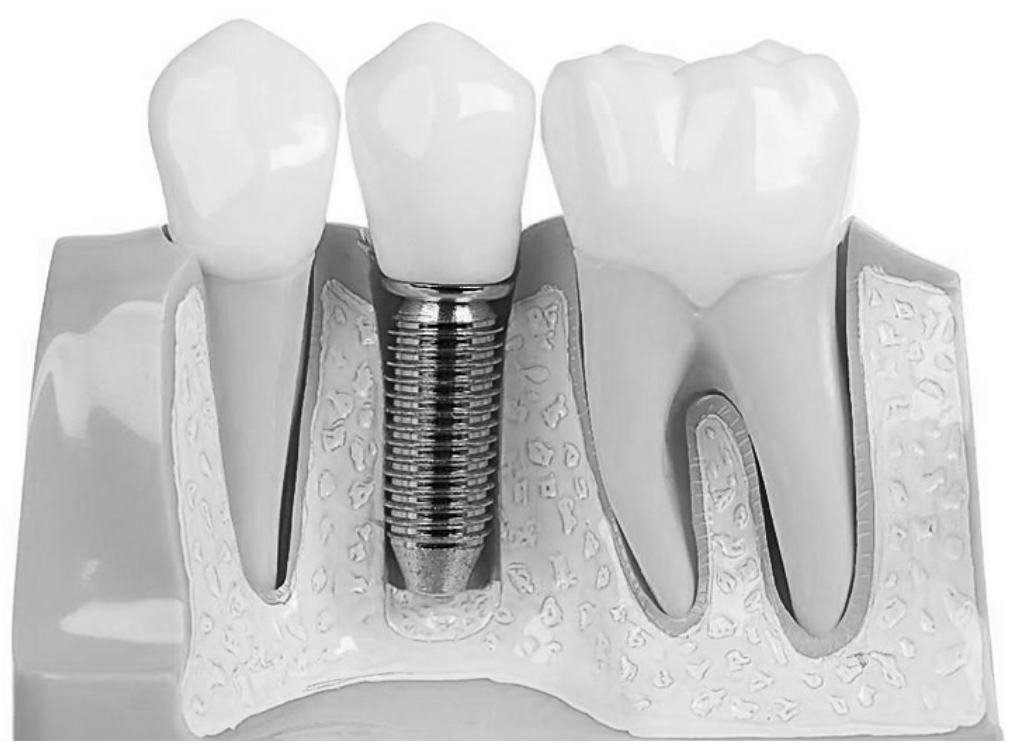

Figure 2. Implant U-Impl

Diagram 1. Trypsin-like indicators of mixed saliva in orthopaedic patients 1 month after implant placement on the background of gastric ulcer and duodenal ulcer ( $\mathrm{mmol} / \mathrm{ml}$ x $\mathrm{min}$ ).

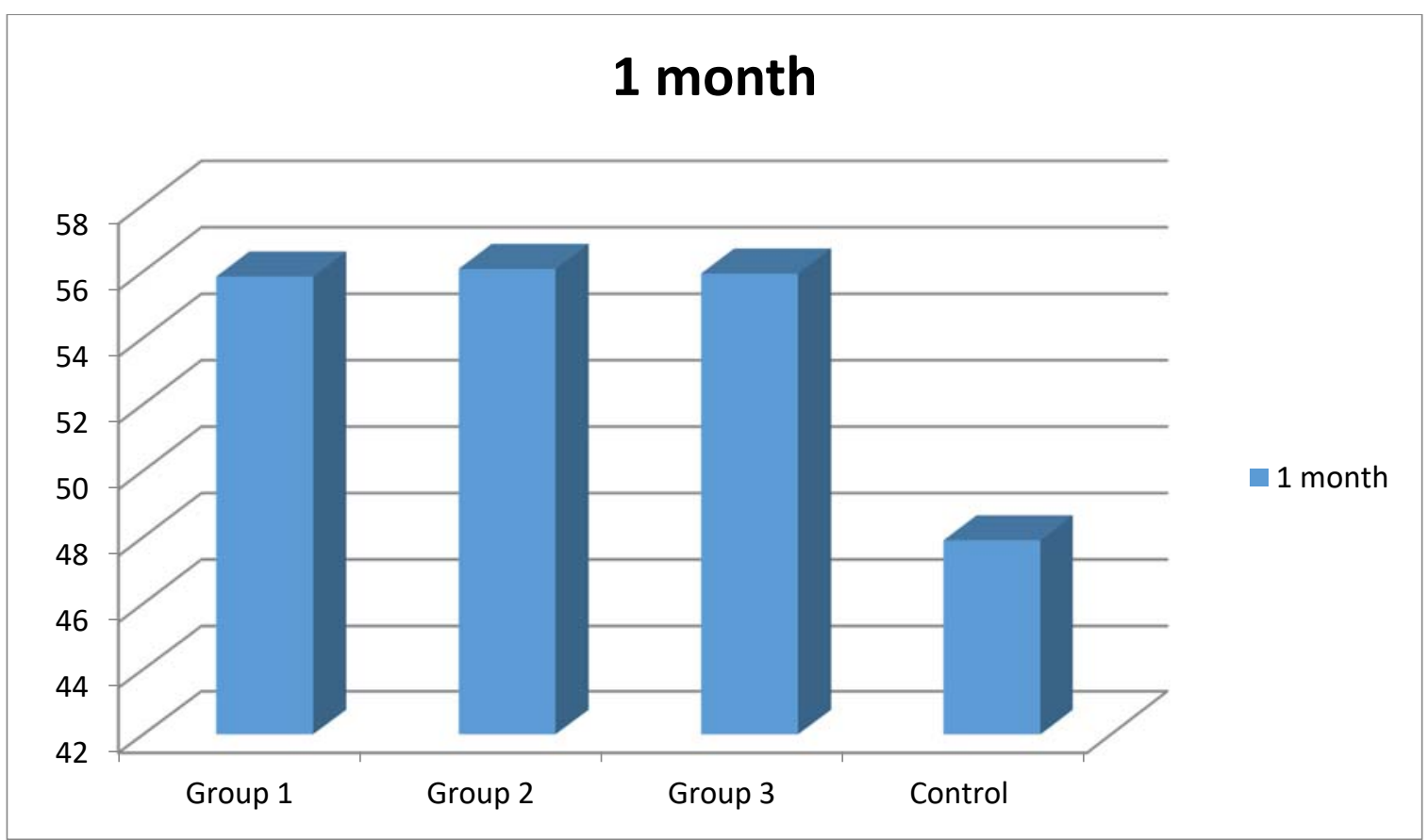


Diagram 2. Trypsin-like indicators of mixed saliva in orthopaedic patients 3 months after implant placement on the background of gastric ulcer and duodenal ulcer ( $\mathrm{mmol} / \mathrm{ml}$ x $\mathrm{min}$ ).

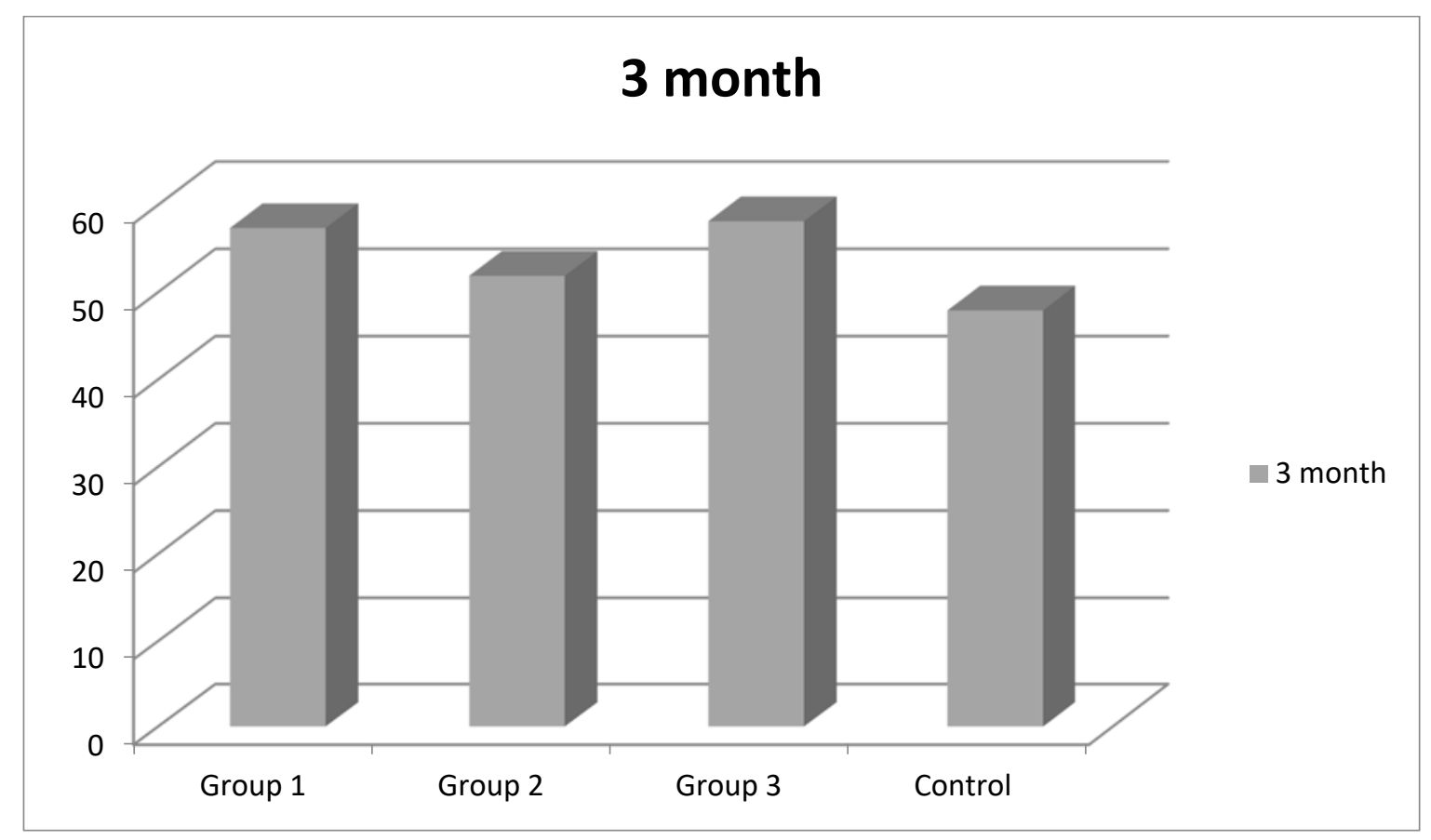

Diagram 3. Trypsin-like indicators of mixed saliva in orthopaedic patients 6 months after implant placement on the background of gastric ulcer and duodenal ulcer ( $\mathrm{mmol} / \mathrm{ml} x \mathrm{~min}$ ).

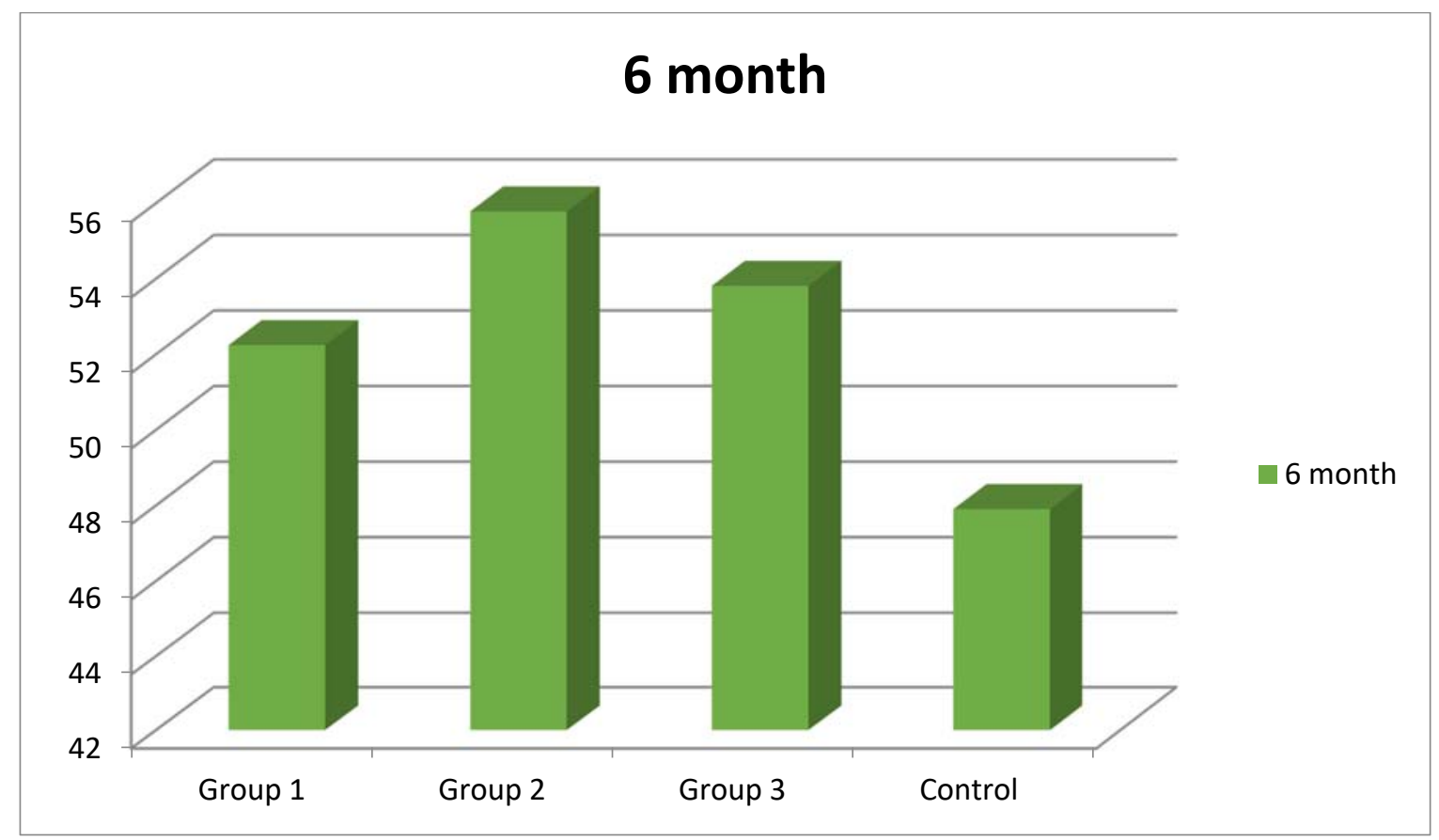


Diagram 4. Trypsin-like indicators of mixed saliva in orthopaedic patients 12 months after implant placement on the background of gastric ulcer and duodenal ulcer ( $\mathrm{mmol} / \mathrm{ml} x \mathrm{~min}$ ).

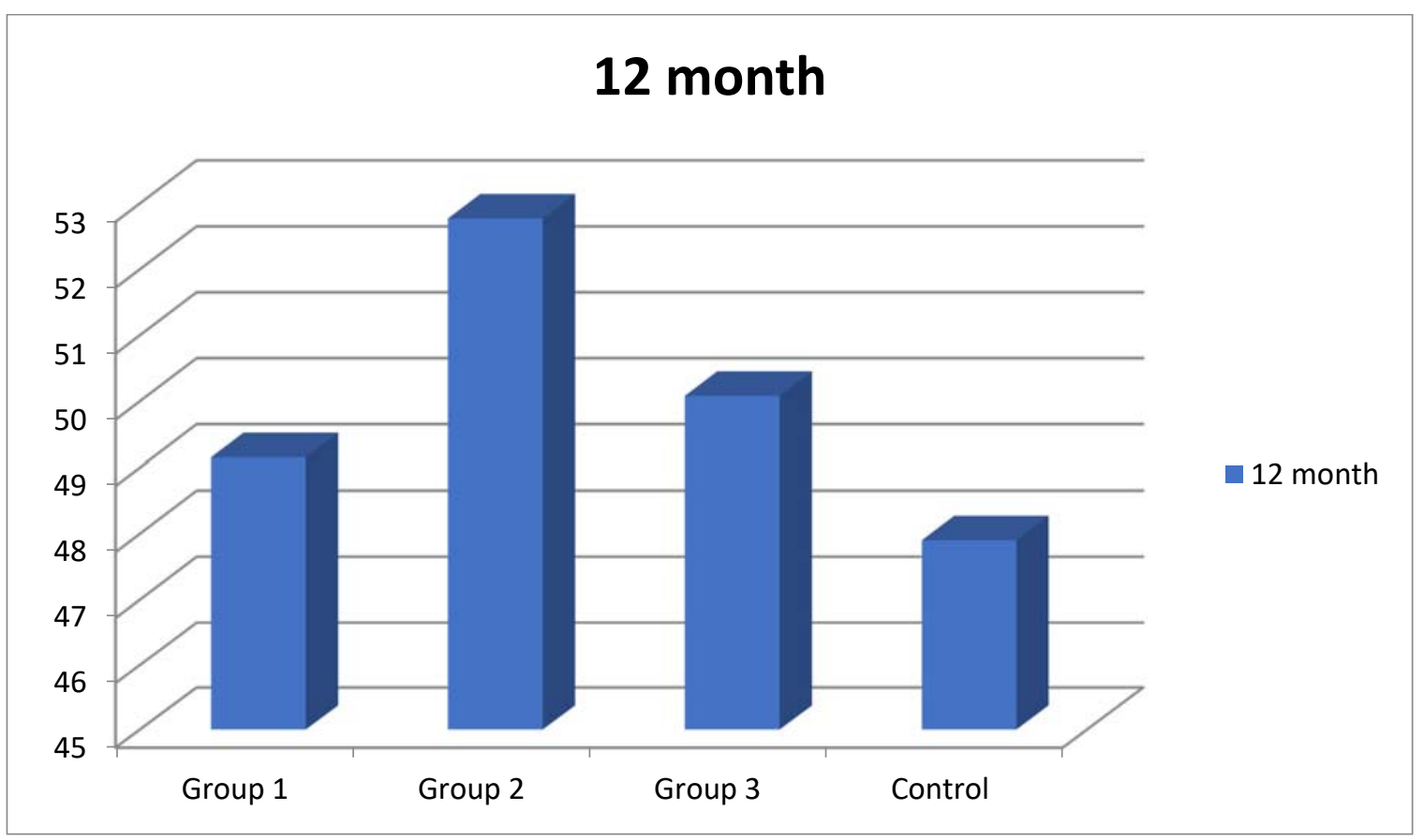

The SOUTHERN BRAZILIAN JOURNAL OF CHEMISTRY (ISSN: 2674-6891; 0104-5431) is an open-access journal since 1993. Journal DOI: 10.48141/SBJCHEM. http://www.sbjchem.com. This text was introduced in this file in 2021 for compliance reasons.

(c) The Author(s)

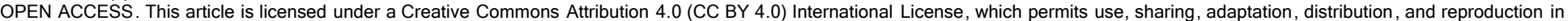

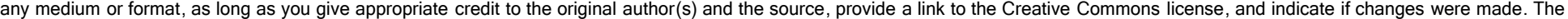

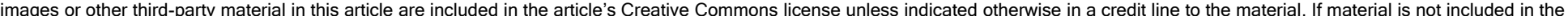

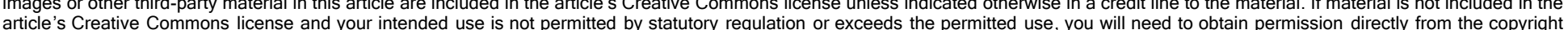
holder. To view a copy of this license, visit http://creativecommons.org/ licenses/by/4.0/.

SOUTHERN BRAZILIAN JOURNAL OF CHEMISTRY. 


\title{
SOUTHERN BRAZILIAN JOURNAL OF CHEMISTRY
}

\author{
NIOBIUM ALLOY STEEL APPLIED IN COLD FORMING MANUFACTURE
}

\author{
MAIA, Bruno Inácio ${ }^{1 *} ;$ FUTAMI, André Hideto²; DE OLIVEIRA, Marco Aurélio³; DALLA \\ VALENTINA, Luiz Veriano Oliveira ${ }^{4}$ \\ 1,2,3,4 Centro Universitário SOCIESC - UNISOCIESC, Mestrado em Engenharia de Produção, Departamento de \\ Pesquisa \\ * Correspondence author \\ e-mail: inaciodamaia@gmail.com
}

Received 06 August 2019; received in revised form 24 October 2019; accepted 21 November December 2019

\begin{abstract}
Niobium alloy steels are still little known and debated when applied to the metallurgy industry, including cold forming process. It is not much clear about its characteristics and your mechanical performance when compared to traditional steels, which the market already uses. The possibility of input new materials, reducing costs and generating competitiveness is the basis for researches that can generate new opportunities for industries. In this article, we showed the possibility of withdrawing the heat treatment process, which guided the execution of the tests presented here. This paper deals with the performance comparison of SAE 1312 MOD steel compared to ISO 898-1, which deals with mechanical performance for bolts. The tests were correlated with the bolts of 8.8 resistance class, which currently have heat treatment. It is possible to evaluate the positive performance of the niobium-alloyed steel (SAE 1312 MOD), despite the occasional performance limitations in some attributes addressed in ISO 898-1.
\end{abstract}

Keywords: Conformation, Niobium, Innovation, Competitiveness, Microalloyed

\section{INTRODUCTION}

Over the years and especially in the 21st century, the production chain has faced various pressures for process optimization and competitiveness gains. Many studies have been trying for years to optimize metallurgical processes, either to achieve technological improvements, gain competitiveness, improve the environment, or simply test new technologies for the development of new products or innovations. This is no different in the fastener industry. In the production stages of the fasteners many inputs are used, and some of them have a strongly negative impact, such as the energy used in the heat treatment which is not (or very little) renewable and the tempering medium that needs a very specific treatment and destination to not become another pollutant $[2,3,4]$.

The achievement of better mechanical properties of the steel, with the optimization of processes and reduction of manufacturing costs, is a permanent objective of the siderurgical companies today. The use of steels with microligants to achieve this purpose has been growing in recent years since with these constituents, and it is possible to obtain a high quality product with lower production costs when compared to the conventional steel manufacturing process $[1,5,6]$.

It is in this scenario that micro-alloyed steels assume a very peculiar role: By its use, some stages of the process can be eliminated, contributing to both the reduction of costs and the decrease of inputs such as energy or quenching medium (water or oil). Since the 1980s, several authors have explored the line of microliges for cold forging and present very consistent results in their work, guaranteeing products that combine good mechanical properties with sufficient ductility in the pieces. These studies are based on the use of various hardening mechanisms presented in metallurgy alternately to the phase transformation reactions represented by the quenching and tempering in the production of fasteners. Using the other hardening mechanisms (solid solution, grain size control, precipitation, and hardening), it is shown in this work the feasibility of producing screws of class 8.8 without the need for the tempering and tempering process $[3,7,9]$.

For the successful use of microalloyed 
steels, the development of chemical composition with a certain amount of microligants is not enough. It is necessary to optimize the parameters of the productive process that influence the properties of the material $[8,10,11]$.

Thus, parameters such as casting and rolling temperature, lamination cooling rate, and degree of cold reduction of the material are determinant for the performance of the properties. For the reasons described above, in this work, process conditions were tested in order to optimize the properties and obtain a product that meets the specifications of the standard ISO 898-1 - Mechanical Properties.

\section{MATERIALS AND METHODS}

The products were manufactured according to drawings, tools, specifications, and cold formed processes by a company, which produces these types of fasteners and has the appropriate machines and equipment to manufacture it. The first step was to cold form in bolt makers machines, the second was the automatic thread laminating, and the last was the heat treatment on automatic and continuous oven, only for bolts made by steel SAE 10B30. The steels used to manufacture the samples were SAE 1312 MOD and SAE 10B30, as shown in Table 1, it contains the chemicals compositions of these materials. The reading and control of steel's chemical composition accomplished through the spectrometer Shimadzu PDA 7000.

Currently, the bolts are produced with SAE 10B30 steel, which fits the requirements for heat treatment and performance 8.8, according to ISO 898-1.

For the production of a lot of small and medium-sized bolts, the forging processes, especially in the cold, present several advantages in relation to the machining process, such as greater utilization of the raw material, higher speed, higher productivity and increased strength due to hardening. The production batch diameter was M16. The SAE 10B30 steel bolts went through the heat treatment process. However, bolts made SAE 1312 MOD steel did not pass - on heat treatment. Both used the same bolt maker for cold forming, and the same set of tooling, the only change in the process was the addition of the heat treatment for SAE 10B30 steel products.

During the process of reheating a microliged steel, the microligant elements are initially present in the form of carbides, nitrides, or carbonitrides. As the temperature is increased, these precipitates gradually dissolve, this dissolution be partial or complete. While present, such compounds inhibit grain growth austenitic. This temperature, solubility limit, can be determined thermodynamically and varies according to the carbon and metal content present in the steel.

Figure 1 confirms the mechanisms of SAE 1312 MOD microstructure. It is clearly observed that at high cooling rates (a), the material becomes predominantly bainitic-ferritic and that, by reducing the rate, the percentage of perlite in the microstructure of the material increases, favoring lower limit values of resistance and flow were not the mechanism of interphase precipitation. In Figure 2, the microstructure of SAE 10B30 without heat treatment can be assessed with an expansion of 500X. The SAE 10B30 micro-alloyed carbon steel does the Perlite matrix with a grain boundary ferrite network.

The tests used to evaluate the performance between samples were specified in ISO 898-1. They were composed of; minimum ultimate tensile loads, Vickers hardness, charpy, Strictness, and proof load. The tests were realized out in the internal metallurgy laboratory of organization, the same equipment was used, and the tests performed by the same operator, 25 samples each one, were used for each measurement type after the dispersion an average of each type of material were evaluated. For the charpy test were used just 5 samples.

After the numerical simulation and engineering projects, two types of samples as inspected, as can be observed according to Figure 3.

The forging forces values obtained with the numerical simulation, to forge samples with different materials can be seen in table 2 . It is possible to visualize the differences in the force of conformation and the percentage of force put on SAE 1312 mod steel.

\section{RESULTS AND DISCUSSION:}

The results obtained can be evaluated in Table 3. According to the comparison between the specification of the standard and the average of the 25 results achieved for each steel type, the product performance and the steel change can be valid. 
The results show the averages of values obtained in the measurement of the 25 types of steel samples, and only the charpy test had 5 samples. Comparing the results of the test force for the bolts manufacturing, approximately $50 \%$ plus force is required if using the SAE $1312 \mathrm{MOD}$ micro-alloyed carbon steel. Therefore, it can be concluded that the wear of labor tends to be higher than that of the bonded SAE 10B30 carbon steel. It is important to consider that the lifespan also depends on other factors that are not oriented to the present, such as the type of lubrication used during the editing, the material used in the manufacturing of the dies (quality and type of tool steel), the thermal treatment of its operations and the surface condition, among others.

It was not possible to evaluate the tool wear because the batch was experimental and was manufactured a small batch. For a more indepth analysis of the tools' performance, it is necessary to make lots of scales and measure the impacts in all tools, stage per stage.

Severe deformations can cause problems like cracks in the material or even the poor filling of material in the head of the bolts. This fact can be related to the presence of sulfur, found in the chemical composition of the micro-alloyed carbon steel, since the same influence in the decrease of the formability of the material.

In Figure 4 , is possible to evaluate the photomicrography microstructure of SAE10B30 steel after austenitization. It is possible to prove the transformation of the material, and the martensitic structure, matrix martensitic revenge level of transformation is $100 \%$, which ensures that the products conforming to this steel comply with the requirements of ISO 898-1.

\section{DISCUSSION:}

It was possible to evaluate in the metallographic analysis that micro-alloyed SAE 1312 MOD steel does not present a martensitic microstructure, but, ferritic-pearlite. The results presented in Table 4, are almost totally in resistance class 8.8 according to ISO 898-1, except for the result of the strictness. The charpy assay is generally required for products with a strength class higher than 8.8 , as ISO 898-1 states that this test may be required for smaller resistance classes, so this study has addressed this situation. The result was negative because it was not in accordance with the $27 \mathrm{~J}$ requested in the standard.

In addition, the conformation of this material presented difficulties in its use, since the simulations showed a greater stamping force necessity for the conformation of the samples. These data may indicate greater wear of the tooling and a limitation according to the severity of the deformations. It's observed as positive results the full attendance to the tests of minimum ultimate tensile loads, proof load, and Vickers hardness. Carbonation, as well as decarburizing, are characteristic of thermally treated parts after forming. Therefore, bolts made of SAE 1312 MOD steel do not suffer from these phenomena.

Due to the results obtained with the physical and mechanical tests carried out in this work, it can be inferred that the SAE 1312 MOD micro-alloyed niobium steel is characteristic because it is a lower ductility material and has less tenacity. Because of this, the physical and mechanical properties established by ISO 898-1 were compromised on strictness test.

\section{CONCLUSIONS:}

This study presents in a succinct and direct way, the possibility of innovating in steel specifications to obtain new products, reducing the process of thermal treatment and to make possible the use of micro-alloyed steel (SAE 1312 MOD) in the cold forming of bolts.

Some immediate benefits can consider the change of steel used may bring to the organization:

o Reduction of operational costs and waste management;

o Optimization of the use of resources, waste, disposal / reduction of waste, effluents, and emissions;

o Gaining environmental awareness throughout the the organization;

o Employee risk reduction and improvement health and safety conditions of the worker;

o Improved operational efficiency of the plant, energy efficiency, increased productivity competitiveness;

o Recovery of some wasted materials, minimization or elimination of raw materials and other inputs that impact the environment;

o Improved company image and greater Clients satisfaction;

o Better compliance with environmental standards, reduction of fines and penalties for pollution, and better relationships with environmental agencies 
and with the community.

For future studies, it is advisable to develop manufacturing batches in smaller gauges to be able to make service comparisons with ISO 898-1. This study complements the current literature in the knowledge field of cold-formed steels involving niobium alloys.

\section{REFERENCES:}

1. El-Kashif, E., Asakura, K., Koseki, T., \& Shibata, K. (2004). Effects of boron, niobium, and titanium on grain growth in ultra high purity $18 \%$ Cr ferritic stainless steel. ISIJ international, 44(9), 1568-1575.

2. Da Maia, B. I., Futami, A. H., \& De Oliveira, M. A. (2018). Vanadium Alloy Steel DIN 30MnVS6 Applied in Cold Forging Process. ISIJ International, 58(12), 2318-2322.

3. Deb, P., \& Chaturvedi, M. C. (1982). Coarsening behavior of cementite particles in a ferrite matrix in $10 B 30$ steel. Metallography, 15(4), 341-354.

4. Maia, B.I., Futami, A. H., \& De Oliveira, M. A. (2018): Nano Ceramic Coating Applied in Surface Treatments. PERIODICO TCHE QUIMICA, 15(30), 357-363.

5. Herbst, S., Schledorn, M., Maier, H. J., Milenin, A., \& Nürnberger, F. (2016): Process Integrated Heat Treatment of a Microalloyed Medium Carbon Steel: Microstructure and Mechanical Properties. Journal of Materials Engineering and Performance, 25(4), 1453-1462.
6. Bock, M., Arrayago, I., \& Real, E. (2015). Experiments on cold-formed ferritic stainless steel slender sections. Journal of Constructional Steel Research, 109, 13-23.

7. DeArdo, A. J. (2003). Niobium in modern steels. International Materials Reviews, 48(6), 371-402.

8. Bleck, W., \& Phiu-On, K. (2005). Microalloying of cold-formable multi phase steel grades. In Materials Science Forum (Vol. 500, pp. 97114). Trans Tech Publications.

9. Klinkenberg, C., Hulka, K., \& Bleck, W. (2004). Niobium carbide precipitation in microalloyed steel. steel research international, 75(11), 744752.

10. Kommel, L., \& Kimmari, E. (2006). Boron carbide based composites manufacturing and recycling features. Materials Science, 12(1), 4852.

11. Rešković, S., \& Jandrlić, I. (2013). Influence of niobium on the beginning of the plastic flow of material during cold deformation. The Scientific World Journal, 2013.

12. Prates, M. B. (2011). Influência do resfriamento na laminação termomecânica de um aço microligado ao nióbio em fio máquina para fabricação de parafusos da classe 8.8.

13. Bueno, K. V. (2012). Desenvolvimento do SAE 1312 modificado ao nióbio para parafusos classe $\quad 8.8$ conformados a frio. 
Table 1. Chemical composition (wt\%) of the SAE 1312MOD and SAE $10 B 30$

\begin{tabular}{|c|c|c|}
\hline Steel & $\begin{array}{c}\text { SAE 1312 } \\
\text { MOD }\end{array}$ & SAE 10B30 \\
\hline $\mathrm{C}$ & 0,12 & 0,32 \\
\hline $\mathrm{Si}$ & 0,23 & 0,28 \\
\hline $\mathrm{Mn}$ & 1,74 & 0,9 \\
\hline $\mathrm{P}$ & 0,022 & 0,01 \\
\hline $\mathrm{S}$ & 0,021 & 0,02 \\
\hline $\mathrm{Cr}$ & 0,23 & 0,37 \\
\hline $\mathrm{Mo}$ & 0,06 & 0,05 \\
\hline $\mathrm{Nb}$ & 0,04 & - \\
\hline $\mathrm{Ni}$ & 0,25 & - \\
\hline $\mathrm{Ti}$ & 0,03 & - \\
\hline $\mathrm{Cu}$ & 0,33 & - \\
\hline $\mathrm{Al}$ & 0,027 & - \\
\hline $\mathrm{N}$ & 0,100 & - \\
\hline $\mathrm{B}$ & - & 0,0025 \\
\hline
\end{tabular}

Table 2. Forging Force

\begin{tabular}{|c|c|c|c|c|}
\hline & \multicolumn{4}{|c|}{ Forging Force (kN) } \\
\hline Material & $\begin{array}{c}\text { 1st } \\
\text { Stage }\end{array}$ & $\begin{array}{c}\text { 2nd } \\
\text { Stage }\end{array}$ & $\begin{array}{c}\text { 3rd } \\
\text { Stage }\end{array}$ & $\begin{array}{c}\text { 4rd } \\
\text { Stage }\end{array}$ \\
\hline $\begin{array}{c}\text { SAE 1312 } \\
\text { MOD }\end{array}$ & 52 & 136 & 15 & 12 \\
\hline SAE 10B30 & 34 & 93 & 10 & 6 \\
\hline $\begin{array}{c}\text { Plus forging } \\
\text { force (\%) SAE } \\
\text { 1312 MOD / } \\
\text { SAE SAE } \\
\text { 10B30 }\end{array}$ & $52,94 \%$ & $46,23 \%$ & $50 \%$ & $50 \%$ \\
\hline
\end{tabular}

Table 3. Tests results for SAE 1312 mod. and SAE 1OB30

\begin{tabular}{|c|c|c|c|c|c|}
\hline $\begin{array}{c}\text { Test Specification } \\
\text { M16 Class 8.8 per } \\
\text { ISO 898-1 }\end{array}$ & $\begin{array}{c}\text { Specification } \\
\text { ISO 989-1 }\end{array}$ & $\begin{array}{c}\text { Results } \\
\text { of SAE } \\
\mathbf{1 0 B 3 0}\end{array}$ & $\begin{array}{c}\text { Standard } \\
\text { Deviation SAE } \\
\mathbf{1 0 B 3 0}\end{array}$ & $\begin{array}{c}\text { Results } \\
\text { of SAE } \\
\mathbf{1 3 1 2} \\
\text { MOD. }\end{array}$ & $\begin{array}{c}\text { Standard } \\
\text { Deviation } \\
\text { SAE 1312 } \\
\text { MOD. }\end{array}$ \\
\hline $\begin{array}{c}\text { Minimum Ultimate } \\
\text { Tensile Loads (N) }\end{array}$ & 125.000 & 142.200 & 7.280 & 128.600 & 1.055 \\
\hline Proof Load (N) & 91.000 & 91.000 & - & 91.000 & - \\
\hline Vickers Hardness, (HV) & $250-320$ & 309 & 10.81 & 260 & 8.77 \\
\hline Charpy (J) "V" -20C & $>27$ & 16 & 2.4 & 14 & 1.8 \\
\hline Strictness (\%) & $>52$ & 54.8 & 1.45 & 28.4 & 3.68 \\
\hline
\end{tabular}


Table 4. Results of testing SAE1OB30 vs SAE 1312 mod

\begin{tabular}{|c|c|c|c|c|c|c|c|}
\hline \multirow{2}{*}{$\begin{array}{l}\text { Test Specification } \\
\text { M16 Class } 8.8 \text { per } \\
\text { ISO 898-1 }\end{array}$} & \multirow{2}{*}{$\begin{array}{l}\text { Specificatio } \\
\mathrm{n} \text { ISO 989-1 }\end{array}$} & \multicolumn{2}{|c|}{$\begin{array}{c}\text { Results of SAE } \\
10 \mathrm{~B} 30\end{array}$} & \multirow{2}{*}{$\begin{array}{c}\text { Status } \\
\text { SAE10B30 }\end{array}$} & \multicolumn{2}{|c|}{$\begin{array}{c}\text { Results of SAE } 1312 \\
\text { MOD }\end{array}$} & \multirow{2}{*}{$\begin{array}{l}\text { Status SAE } \\
1312 \text { MOD }\end{array}$} \\
\hline & & Min. & Max. & & Min. & Max. & \\
\hline $\begin{array}{l}\text { Minimum Ultimate } \\
\text { Tensile Loads }(\mathrm{N})\end{array}$ & 125.000 & 134.920 & 149.480 & OK! & 127.545 & 157.155 & OK! \\
\hline Proof Load (N) & 91.000 & 91.000 & - & OK! & 91.000 & - & OK! \\
\hline $\begin{array}{c}\text { Vickers Hardness, } \\
(\mathrm{HV})\end{array}$ & $250-320$ & 298.19 & 319.81 & OK! & 251,23 & 285.63 & OK! \\
\hline $\begin{array}{c}\text { Charpy (J) "V" - } \\
20^{\circ} \mathrm{C}\end{array}$ & $>27$ & 13.60 & 18.40 & $\mathrm{X}$ & 12.20 & 16.60 & $\mathrm{X}$ \\
\hline Strictness $(\%)$ & $>52$ & 53.35 & 56.25 & OK! & 24,72 & 47.88 & $X$ \\
\hline
\end{tabular}

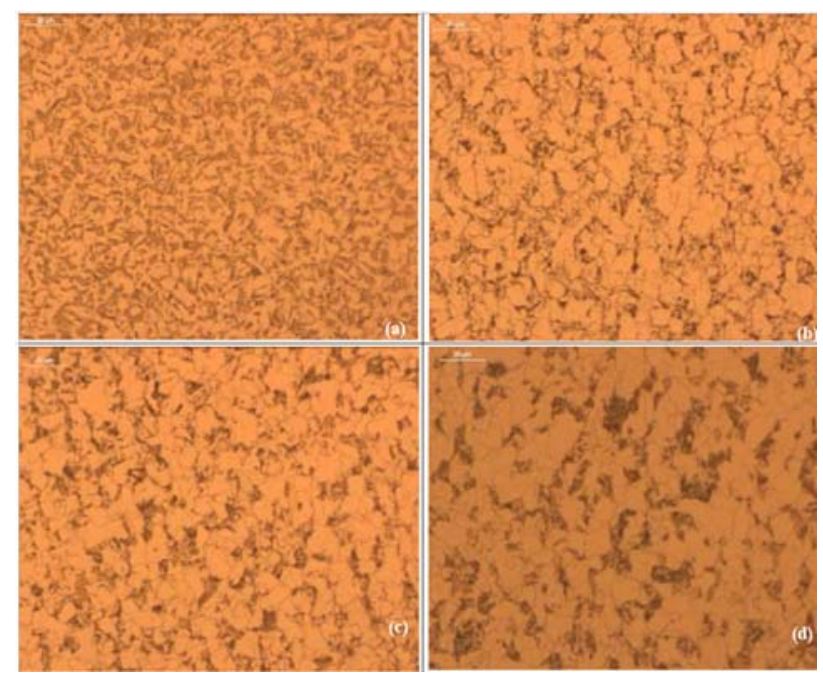

Figure 1. Optical micrographs of SAE 1312 mod steel coiled at high temperature with cooling rate: (a) high; (b) mean; (c) low and (d) very low.

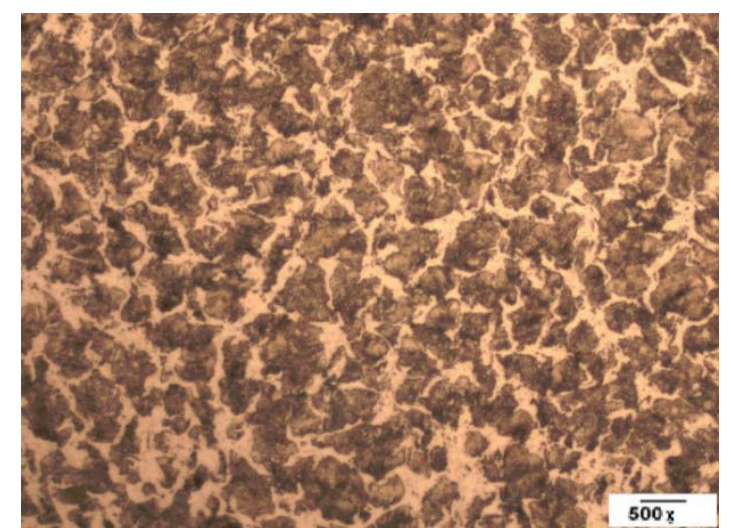

Figure 2. Photomicrography of SAE 10B30 without heat treatment (expansion 500X) 

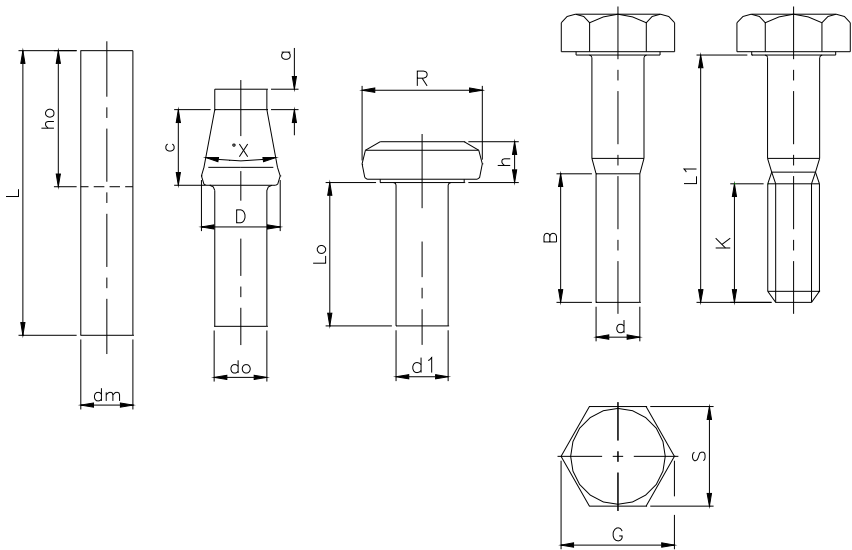

Figure 3. Bolts Samples. SAE1312 Mod. Steel.

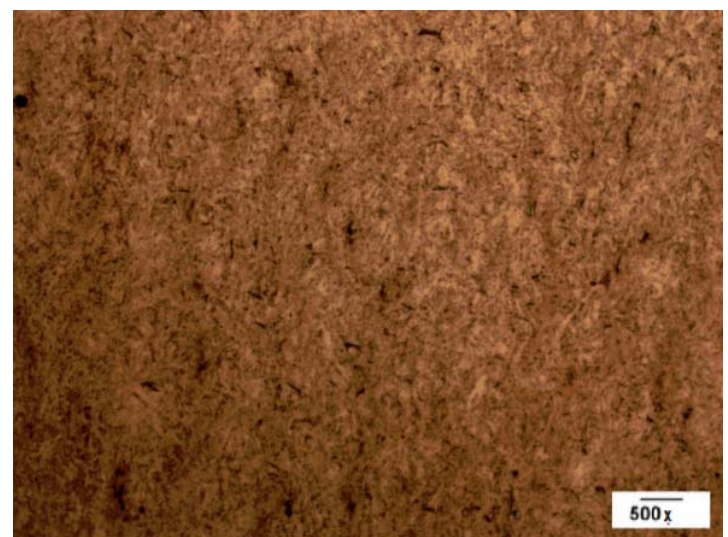

Figure 4. Photomicrography of SAE 10B30 with heat treatment (expansion 500X)

The SOUTHERN BRAZILIAN JOURNAL OF CHEMISTRY (ISSN: 2674-6891; 0104-5431) is an open-access journal since 1993. Journal DOI: 10.48141/SBJCHEM. http://www.sbjchem.com. This text was introduced in this file in 2021 for compliance reasons.

(c) The Author(s)

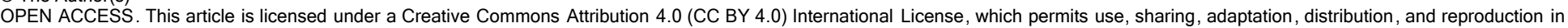

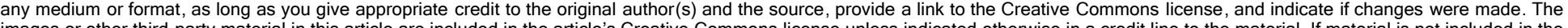

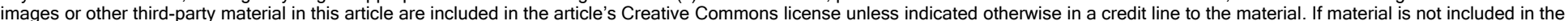

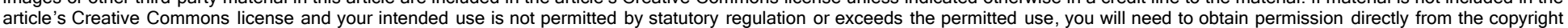
holder. To view a copy of this license, visit http://creativecommons.org/ licenses/by/4.0/. 


\title{
SOUTHERN BRAZILIAN JOURNAL OF CHEMISTRY
}

\section{PRODUCTION OF BIOPLASTIC FROM POTATO STARCH}

\author{
CORDEIRO, Paula Novais ${ }^{1 *}$; CAETANO, Skarllet Toledo²; DE CARVALHO, Raquel Moreira \\ Maduro $^{3}$
}

\author{
${ }^{1,2,3}$ Departamento de Engenharia Química, União de Ensinos Superiores de Viçosa, Viçosa, MG \\ * Autor correspondente \\ E-mail: paulacordeiro002@hotmail.com
}

Received 25 October 2019; received in revised form 30 November 2019; accepted 08 December 2019

\begin{abstract}
Due to their diverse properties, plastic materials are used in numerous sectors. It is possible to produce different articles and plastic objects with reduced costs, being more accessible to the population. Conventional plastics are obtained from petroleum-derived raw materials, a non-renewable resource in which their extraction and refining process cause major environmental impacts. The production of plastic reaches a level of approximately one hundred and forty million tons per year, and the disposal of these materials is increasing, generating a high rate of waste and leading to an increase of pollution since the decomposition of these materials lasts about five hundred years old. Conventional plastics can be replaced by bioplastics, a material obtained from renewable raw materials such as potatoes, cassava, maize, and which, when disposed of under favorable conditions, decomposes faster, as during its degradation process at least one step occurs. Through the metabolism of organisms present in the environment. Starch has been widely used in the production of biodegradable packaging, so the objective of this work was to produce a biodegradable bioplastic from the potato starch. Potato starch, glycerin, hydrogen peroxide, distilled water, and commercial agar were used to produce the bioplastic. Bench-scale bioplastics had good organoleptic characteristics, similar in appearance to a conventional plastic obtained from petroleum. The thickness, moisture content, and solubility of the bioplastics were analyzed, as well as their fruit preservation capacity. The samples produced were rigid and with good resistance.
\end{abstract}

Keywords: Plastics, Bioplastics, Starch

\section{INTRODUCTION}

Plastic is an organic and synthetic polymer, solid in your final stage as a finished product, and at some point, in its production phase was turned to fluid, suitable for molding by the actions of heat and pressure (Piatti e Rodrigues, 2005). Most of the industrial plastic materials have petroleum as raw material, a nonrenewable natural source (Telles, 2011). Among the most used plastics, it is possible to highlight the polypropylene (PP), high density polyethylene (HDPE) and low density (LDPE). Currently, 140 million tons of plastic are produced per year, distributed between different products. This number is related to the easy processing and low cost of this material (Oliveira, Lacerda, Alves, Santos, Oliveira, and Batista, 2012; Macedo, 2015).

Plastic is a material of difficult compaction, which can lead to waste accumulation in the environment, also compromising the decomposition of other organic materials. Plastic material is resistant to fungi and bacteria, resulting in a slow degradation. In direct contact with the environment, it can take around 100 thousand years to be decomposed. Most of its waste is discarded at dumps and landfills, leading to concern around the disposal process (Machado, 2011; Franchetti, Marconato, 2006).

In Brazil, approximately 25 thousand ton of plastic packing are discarded every day, which compose $20 \%$ of all waste produced, and $80 \%$ of these plastic packings are used only once before going to thrash (Ministério do Meio Ambiente, 2016).

Due to the great environmental impact caused by the use of plastic products, in the past years has been studied alternative routes to obtain plastics made by renewable sources, such as bioplastics. This material is similar to conventional plastic, though its degradation time is much shorter, showing to be a much more ecological option (Rodríguez, 2012; MorenoBustillos, Humarán-Sarmiento, Báez-Valdez, Báez-Hernández and León-Villanueva, 2017). 
The bioplastics have physical and chemical properties similar to conventional plastics, but its degradation can take from 18 to 20 months, reducing the time in contact with the environment. This process is a result, mainly, by the action of microorganisms like fungi, bacteria, and naturally occurring algae (Santos, 2014; Giordani; Oliveira, 2014).

The term bioplastic refers to all plastic material containing organic raw material, but the fact of the raw material being organic does not necessarily indicate that the material will be biodegradable. The bioplastics are the ones that degrade easily through the the composting process or water-soluble bioplastics, which which can have its degradation process started by the air humidity (ABES, 2016; Valero-Valdivieso, Ortegón, Uscategui, 2013).

Several researches about the production of bioplastics using natural and renewable raw materials like castor oil, sugar cane, beets, lactic acid, corn, soya protein, potato, and cassava starch are being realized around the world.(Telles, 2011; Giordani; Oliveira, 2014). In proper conditions (Temperature, humidity, and oxygen availability), the degradation of biopolymers leads to disintegration with non-toxic and not dangerous waste(Fonseca, 2014).

The bioplastics can be extracted straight from biomass, like cellulose and starch, produced by natural or genetic modified microorganisms like PHA, PHAB and TPS, obtained from biointermediators like polylactic acid/PLA, Green PET/PlantBottle ${ }^{\circledR}$, biodegradable plastics obtained from conventional plastics additives like Ecoflex/Ecovio from BASF and conventional plastics produced by renewable raw materials like polyethylene obtained from sugar cane ethanol (Prandella, 2006; Correa, 2018).

Many biopolymer applications depend on their properties, such as; mechanical, thermic, gas, and water vapor barriers. The biopolymers have properties similar to conventional polymers. They can be used to produce every type of package (trays, cups, bottles, monolayer films, laminates, composites, etc.) using the same processing step, as long as adjusted according to its properties (Coltro, Sarantópoulos, Jesus Jr, 2005).

Starch is an abundant raw material present in nature that possesses a relatively low cost, has been used in biodegradable packing production, thus being studied as a replacement for petroleum, due to the fact of being renewable, biodegradable source and toxin less, making possible food applications (Fakhouri, 2009). In 2011 , starch mixtures were responsible for $11,3 \%$ of produced bioplastics, but due to the increase in research around this topic, this number may increase (Priendniece, Spalvins, Ivanovs, Pubule, Blumberga, 2017).

Due to these characteristics, this project seeks the study and production of a biodegradable bioplastic made from white potato starch and evaluate its physical and chemical properties.

\section{EXPERIMENTAL SECTION}

The bioplastics were produced using potato starch, glycerin, hydrogen peroxide, distilled water, and commercial agar.

In a blender, it was added 530 grams of washed potatoes and $500 \mathrm{~mL}$ of distilled water, according to Pinto (2016). The obtained material was strained and kept at rest for approximately 10 minutes, to separate the starch by decantation. The extracted starch was divided into two portions of 5.6 grams each. The portions were solubilized in $25 \mathrm{~mL}$ of distilled water.

The bioplastic was obtained by two different methods, Almeida, Almeida and Miranda Leite (2014) and Santos (2013): on the first, it was added $1 \mathrm{~mL}$ of glycerin; 1.12 grams of commercial agar and $1 \mathrm{~mL}$ of hydrogen peroxide at $35 \%$. On the second, the reaction order was modified, adding $1 \mathrm{~mL}$ of hydrogen peroxide, 1 $\mathrm{mL}$ of glycerin, and 1.12 grams of commercial agar. other mixtures were heated to $60^{\circ} \mathrm{C}$, being stirred by a glass rod until boiling point. Posteriorly, the mixtures were transferred to a Styrofoam tray and stayed in an incubator for 2.4 hours at $40^{\circ} \mathrm{C}$.

It was observed visible changings on the sample characteristics like color, aspect, hardness, texture, and odor. The determination of humidity of the produced materials was made in triplicates. For each produced bioplastic, it was removed 3 samples of approximately $2 \mathrm{~cm}^{2}$, which were weighted and placed in an incubator for 24 hours at $105^{\circ} \mathrm{C}$ (Silva, 2011). The humidity was obtained using Equation 1:

$$
h=\frac{(m i-m f)}{m i} * 100 \%
$$

Where $h$ is the humidity percentage, $m i$ is the initial mass and $m f$ the final mass after drying.

The solubility determination was made in duplicates. For each bioplastic, a sample of $2 \mathrm{~cm}^{2}$ 
was obtained and placed in an incubator for 24 hours at $105^{\circ} \mathrm{C}$. Then, the sample was weighted (mi) and placed inside a beaker with $10 \mathrm{~mL}$ of distilled water for 24 hours at $25{ }^{\circ} \mathrm{C}$. Posteriorly, the bioplastic was placed in the incubator for 24 hours at $105{ }^{\circ} \mathrm{C}$ to dry. The sample was weighted, obtaining the final mass $(m f)$ (Silva, 2011). Thus, it was possible to determine the mass loss $(p m)$ by solubilization, using equation 2:

$$
p m=\frac{(m i-m f)}{m i} \text { (Eq. 2) }
$$

Where $p m$ is the mass loss, $m i$ the initial mass obtained in the first weighting and $m f$ the final mass. The bioplastic film thickness was measured using a caliper rule. Controlling the film thickness, it is possible to evaluate the homogeneity of these materials, the repeatability of its properties measurements, and validate the comparison between different films (Silva, 2011).

To evaluate the barrier properties, it was used apple slices wrapped with bioplastic and placed at room temperature. In order to compare, one slice was wrapped in commercial plastic (petrol based), and one slice was not wrapped, used as the negative control. The samples were analyzed and compared after 5 days (Silva, 2011).

\section{RESULTS AND DISCUSSION:}

The produced bioplastics presented a rigid aspect, with no cracking, odorless, and colorless. These characteristics were also observed in bioplastics produced previously, also using potato starch as raw material (Almeida, Almeida, and Miranda Leite, 2014).

Both samples presented consistent films with a certain flexibility. This characteristic was obtained because of the presence of glycerin, which increases the mobility of macromolecular chains. This aspect was also observed by Neves and his colleagues in 2013, where bioplastics were produced from potato peel. The high stability and clear aspect are associated with the presence of hydrogen peroxide, since, with the starch oxidation, it is possible to modulate its properties and increase its usage (Brites, 2013).

The firmer appearance presented by the bioplastics is due to the high concentration of amylose. According to Santana (2013), the ratio between amylose and amylopectin affects the bioplastics morphology, a high amylose concentration leads to more homogeneous films, with better mechanical and barrier properties while a high amylopectin concentration leads to separation, with more fragile films.

Image 1 presents the produced bioplastics. The bioplastic 1 showed to be more similar to the conventional plastic, due to its lower thickness.

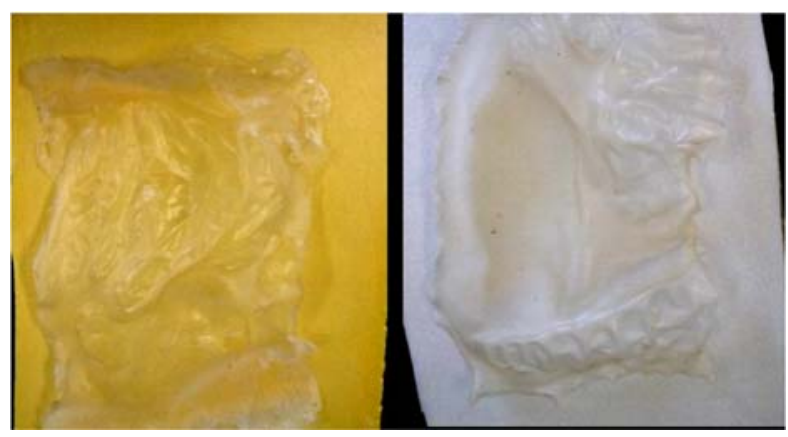

(a)

(b)

Image 1: Produced Bioplastics(a) Bioplastic 1, (b) Bioplastic 2

Source: Author.

The thickness determined by direct measurement, using a caliper rule, was $0.04 \mathrm{~mm}$ for bioplastic 1 and 0.052 for bioplastic 2. This variation can be related to the way how the bioplastic was spread onto the Styrofoam surface. Since the mixture presents a high viscosity after the heating step, the molding step showed to be difficult.

According to Vasconcellos (2014), a conventional polypropylene (PP) film has a thickness around $0.03 \mathrm{~mm}$. Thus, it is possible to state that the produced bioplastics had a similar thickness to petroleum-based polymers. During the film production, it was observed that films with higher thickness had problems during the drying step, with no film formation.

The produced bioplastics dried correctly because of the thin thickness obtained. The average humidity of the bioplastics was $25.34 \%$ and $26.18 \%$, respectively. These values are within the limit set by cassava starch bioplastics, which varies from $14.58 \%$ to $51.61 \%$ (Santos, 2013). It is possible to compare these values because of the similar humidity range obtained for both cassava and potato starch-based bioplastics. Tough, studies say that the humidity concentration must be $10 \%$ maximum, so the film presents good barrier properties (Silva, 2011).

The water solubility is one of the properties that characterize a good biodegradable film. A low water solubility characterizes a good bioplastic (Junior, 2009). The solubility index of the produced bioplastics 
was $26.1 \%$ for bioplastic 1 and $23.6 \%$ for bioplastic 2 . The potato starch and glycerin films showed solubility values of around $31.7 \%$ (Wang, Jin, \& Yuan, 2007). The bioplastics presented a good resistance, which can be related to the low solubility index in comparison to the studies in potato starch bioplastics.

The produced bioplastics presented a good degradability in comparison to conventional plastics. This result can be seen in studies made by Azevedo, Almeida e Santos (2017), where was used several natural polymers, among them the potato starch.

The use of bioplastic as food coating was analyzed using apple slices. It was used: (a) A slice wrapped in bioplastic 1, (b) a slice wrapped in bioplastic 2, (c) a slice wrapped in conventional plastic, petroleum-based, and (d) a fourth sliced used as a negative control, with no coating. Image 2 is possible to observe the aspect of the slices after 5 days.

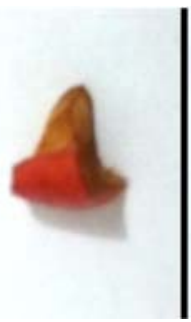

(a)

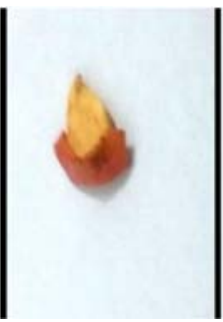

(b)

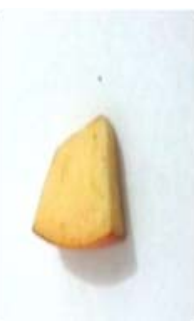

(c)

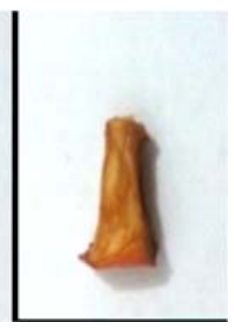

(d)
Image 2:Apple slices after 5 days of exposure.

Source: Author.

Image 2 showed that the better coating was made by conventional plastic. This indicates that the barrier property of the conventional plastic is better than the bioplastics. This also can be related to the high humidity found in the produced bioplastics. The air humidity, associated with the bioplastic humidity affected the fruit conservation, even when compared with the negative control. It is possible to observe that the bioplastic 2 conserved the apple slice better than bioplastic 1 . Bioplastic 2 presented a lower solubility index than bioplastic 1 , which could have influenced the difference in conservation between the two bioplastics.

At research made by Silva (2011), similar results were founded for bioplastics produced from pine cone starch, where three apples, one coated with the biofilm, one with conventional plastic and negative control, were evaluated. Inthe experiment, it was also observed that the conventional plastic had better results in comparison to the bioplastic, which was explained by the good permeability to ethylene by the conventional plastic, fundamental factor to fruit conservation.

\section{CONCLUSIONS:}

In this work, it was produced a bioplastic of white potato starch. The produced bioplastic presented good organoleptic characteristics, with similar aspects to a conventional plastic made of petroleum.

During the research, it was observed that the determination of the film thickness has great importance due to the fact that a high thickness does not allow a good film formation. The thickness obtained in this work was considered satisfactory since it was similar to polypropylene films.

The humidity concentration presented in the biofilms was considerate high, where the films with the best barrier properties for water and air possess a low humidity index, around $10 \%$. The produced biofilms presented a rigid aspect, with good resistance, which is associated with the low water solubility index presented by the biofilms.

In the future, it is suggested the realization of permeability studies, to increase the bioplastics properties in food conservation. Mechanical tests, like tensile, stress.

\section{ACKNOWLEDGEMENTS:}

First, I thank God for empowering me, my parents and my brother, my son Heithor, my mentor Skarllet Toledo for dedication, patience, encouragement, and advice, my friends and coworkers for helping me on my journey.

\section{REFERENCES:}

1. Piatti, T. M. Rodrigues, R. A. F. Série: Conversando sobre Ciências em Alagoas. Ed. EdufalMaceió, 2005. 51p.

2. Telles. M. R. Saran. L.M. UnêdaTrevisolli. S.H. Ciência\&Tecnologia: FATEC-JB, Jaboticabal, v. 2, n. 1, p. 5263, 2011.

3. Oliveira, L. L., Lacerda, C. S., Alves, I. J. B. R., Santos, E. D., Oliveira, S. A., Batista, T. S. A. BioFar, Revista de Biologia e Farmácia, v. 07, n.1, p. 88-104. Campina Grande, Paraíba, 2012.

4. Macedo, M.J.M.F. Dissertação de Mestrado. Universidade do Minho. 
Portugal, 2015.

5. Machado, R.C. [homepage na internet]. Plástico meioambienteumarelaçãopossível?

Ciência e Cultura. Setembro, 2011 [acessoem 23 set. 2016]. Available at: http://www.cienciaecultura.ufba.br

6. Franchetti, S.M.M.; Marconato, J.C. Química Nova, v. 29, n. 4, p.811-816, 2006.

7. Ministério do MeioAmbiente [homepage na internet]. Impacto das embalagens no meioambiente [acessoem 25 set. 2016]. Available at: http://www.mma.gov.br

8. Rodríguez, A. Ciência e Tecnologia de Alimentos. Vol. 22, No. 3, p. 69-72, Cuba, 2012.

9. Moreno-Bustillos, A. I., HumaránSarmiento, V., Báez-Valdez, E. P. , BáezHernández, G. E. e León-Villanueva, A. RA XIMHAI 13 N.3 Edição Especial, 365382, México, 2017.

10. Santos. B. Coelho. T. M. Filho. N. A. IX EPCT - Encontro de ProduçãoCientífica e Tecnológica, 2014.

11. Giordini, A. Oliveira, A.M.S. Trabalho de Conclusão de Curso. Universidade Federal de Alfenas, Minas Gerais, 2014.

12. ABES. Associação brasileira de engenharia sanitária e ambiental [homepage na internet]. Os bioplásticos são realmente uma boa escolha? [acessoem 01 out. 2016]. Disponivélemhttp://www.abes-mg.org.br

13. Valero-Valdivieso, M.F. Ortegón, Y. Uscategui,Y. Dyna rev.fac.nac.minas vol.80 n.181 Medellín, 2013.

14. Fonseca, C. C. Trabalho de Conclusão de Curso. Universidade de São Paulo, Escola de Engenharia de Lorena, 2014.

15. Prandella, J. G.C. Centro de Gestão e Estudos Estratégicos. São Paulo, Maio, 2006

16. Correa, C. A. I Seminário Internacional Oceanos livres de Plásticos p. 126-143 UNISANTA Bioscience Vol. $7 \mathrm{n}^{\circ} 6$ Edição Especial (2018).

17. Coltro, L., Sarantópoulos, C.I. G. L.,Jesus $\mathrm{Jr}$, I. Artigo Científico. Centro de Tecnologia de Embalagens. Faculdade de Engenharia Química - Unicamp. $8^{\circ}$ CongressoBrasileiro de Polímeros, 2005.

18. Falkhouri, F. M. Tese de doutorado Universidade Estadual de Campinas. São Paulo, 2009.
19. Priendniece, V. Spalvins, K., Ivanovs, K., Pubule, J., Blumberga, D. Environmental and Climate Technologies. De Gruyter. Vol. 21, pp. 18-27, Letônia, 2017.

20. Pinto, A.P. FichaCientifica. Grupo de QuímicosJovens. ChemRusquímica online, 2016.

21. Almeida, C. Almeida, F. Miranda Leite, E. $54^{\circ}$ CongressoBrasileiro de Química. 2014.

22. Santos. B. Silva.R. S. Coelho. T. M. Filho. N. A. VIIIIII EPCC - Encontro Internacional de ProduçãoCientíficaCesumar. Ed. Cusumar. 2013.

23. Silva, E. M. Trabalho de Conclusão de Curso. Universidade Federal do Rio Grande do Sul, 2011.

24. Neves, J. M., Aquino, L. B. L., Vilmar, L. S., Almeida, N. G., Silva, T. S. S. M., Duarte, T. K. C. XLI CongressoBrasileiro de Educaçãoem Engenharia.

Gramado, Rio Grande do Sul, 2013.

25. Brites, L. T. G. F. Dissertação de Mestrado. Universidade Estadual de Ponta Grossa, 2013.

26. Santana, R. F. Dissertação de Mestrado. Engenharia de Alimentos.Universidade Estadual do Sudoeste da Bahia, 2013.

27. Vasconcellos, M.P.R. Trabalho de Conclusão de Curso. Universidade de São Paulo, 2014.

28. Junior, M.D.M, Dissertação de Mestrado. Universidade de São Paulo, 2009.

29. Wang, Jin, \& Yuan. Preparation of resistant starch from starch-guar gum extrudates and their properties. Food Chemistry, v. 101, p. 20-25, 2007.

30. Azevedo, A. R. Almeida, V.M. Santos, S. A. S. Conhecimento e Diversidade, Niterói, v. 9, n. 19, p. 59-70, 2017.
The SOUTHERN BRAZILIAN JOURNAL OF CHEMISTRY (ISSN: 2674-
$6891 ; 0104-5431$ ) is an open-access journal since 1993. Journal DOI:
10.48141/SBJCHEM. http://www.sbjchem.com. This text was
introduced in this file in 2021 for compliance reasons.
() The Author(s)
OPEN ACCESS. This article is licensed under a Creative Commons
Attribution 4.0 (CC BY 4.0) International License, which permits use, sharing,
adaptation, distribution, and reproduction in any medium or format, as long as
you give appropriate credit to the original author(s) and the source, provide a
link to the Creative Commons license, and indicate if changes were made. The
images or other third-party material in this article are included in the article's
Creative Commons license unless indicated otherwise in a credit line to the
material. If material is not included in the article's Creative Commons license
and your intended use is not permitted by statutory regulation or exceeds the
permitted use, you will need to obtain permission directly from the copyright
holder. To view a copy of this license, visit http ://creativecommons .org/
licenses/by/4.0/. 


\section{SOUTHERN BRAZILIAN JOURNAL OF CHEMISTRY}

\section{PREPARATION OF MANUSCRIPTS}

Please, observe the following points in preparing manuscripts. Papers not conforming strictly to these instructions may be returned to their authors for appropriate revision or may be delayed in the review process.

Readability: Manuscripts should be written in clear, concise, and grammatically correct English (British or American English throughout). The editors cannot undertake wholesale revisions of poorly written papers. Every paper must be free of unnecessary jargon and clearly readable by any specialist of the related field. The abstract should be written in an explanatory style that will be comprehensible also to readers who are not experts in the subject matter.

General format: The complete paper has to be written preferably in an MS-Word (Ms-Word 2003 or MSWord 2007) or in a Libre.Office (.odt) compatible file. Page size: as in the template, line spacing: single, font type: Arial. Please leave headers and footers unchanged, since it should be filled by the editors. Please check guidelines for accurate information based on all different categories (review articles, technical notes, etc.) available. A single file of the whole manuscript should then be submitted through SBJChem's email. The Journal no longer accepts submissions in any other form.

The order of the material should be as follows: Title, Author(s), Abstract, Keywords, Main text (Introduction, Review of Literature, Definitions (if any), Materials and Methods, Results, Discussion), Acknowledgements (if any), References, Appendix (if any). This structure of the main text is not obligatory, but the paper must be logically presented. Footnotes should be avoided. The main text must be written with font size 11, justify. Within each main section, three levels of subheadings are available, and the titles must be with bold, bold and italic, italic respectively.

The manuscript should contain the whole text, figures, tables, and explanations according to the followings (we suggest using the template file):

The first page of the material should be as follows:

Title: Should be brief and informative. The title should reflect the most important aspects of the article, in a preferably concise form of not more than 100 characters and spaces. Font size 12, capital letters, center alignment.

By-line: Names (size 12, small capital) of the authors. No inclusion of scientific titles is necessary. In case of two or more authors, place their names in the same row, separate them with a semicolon (;) and please indicate the corresponding author with * in superscript. The corresponding author should be the one submitting the article online and an e-mail given (only one e-mail) below the addresses of all authors. Authors from different institutions must be labeled with numbers in superscript after the names. Addresses of the authors, phone and fax number, should also be given (size 10). Authors should be grouped by address.

Abstract: Required for all manuscripts in which the problem, the principal results, and conclusions are summarized. The abstract must be self-explanatory, preferably typed in one paragraph and limited to max. 300 words. It should not contain formulas, reference, or abbreviations. The word ABSTRACT should be written in capital letters, Arial, size 12, bold, left alignment. The abstract should be written font Arial, size 10, justify.

Keywords: Keywords should not exceed five, not including items appearing in the title. The keywords should be supplied, indicating the scope of the paper. Size 10, italic, justify, only the word Keywords must be bold, left alignment.

\section{Authors should include Abbreviations and Nomenclature listings when necessary.}

The main text part of the material should be as follows:

The words Introduction, Materials, and Methods, Results and Discussion, Conclusion, Acknowledgements, and References must be written in capital letters, Arial, font size 12, left alignment, bold.

Introduction: The introduction must clearly state the problem, the reason for doing the work, the hypotheses or theoretical predictions under consideration, and the essential background. It should not contain equations or mathematical notation. A brief survey of the relevant literature so that a non-specialist reader could understand the significance of the presented results. 


\section{SOUTHERN BRAZILIAN JOURNAL OF CHEMISTRY}

Materials and Methods: Provide sufficient details to permit repetition of the experimental work. The technical description of methods should be given when such methods are new.

Results and Discussion: Results should be presented concisely. Also, point out the significance of the results and place the results in the context of other work and theoretical background.

Conclusion: Summarize the data discussed in the Results and Discussion showing the relevance of the work and how different it is from other researches. Also, point out the benefits and improvements that can be observed in order to develop new science standards that can change something in the related field.

Acknowledgments: (if any) These should be placed in a separate paragraph at the end of the text, immediately before the list of references. It may include funding information too.

References: In the text, references should be cited in the Harvard style (Author, year). Alternatively, the author's surname may be integrated into the text, followed by the year of publication in parentheses. Cite only essential resources, avoid citing unpublished material. References to papers "in the press" must mean that the article has been accepted for publication at the end of the paper list references alphabetically by the last name of the first author. Please, list only those references that are cited in the text and prepare this list as an automatically numbered list. The word References with size 12, bold, capital letters, left alignment.

\section{Guidelines for References}

Journals

Journal abbreviations should be used, as defined by the Chemical Abstracts Service Source Index (see http://www.cas.org/sent.html). If the official short form can not be determined, and it is not apparent how to abbreviate the title, the full journal title should be given.

1. Varma, R. S.; Singh, A. P.; J. Indian Chem. Soc., 1990, 67, 518.

If the journal cannot be easily accessed, its Chemical Abstracts number should be given, as follows:

2. Provstyanoi, M. V.; Logachev, E. V.; Kochergin, P. M.; Beilis, Y. I.; Izv. Vyssh. Uchebn. Zadev.; Khim. Khim. Tekhnol. 1976, 19, 708. (CA 85:78051s). as follows:

If the article has a DOI number, but its complete reference is not given, the DOI number should be cited

3. Vidotti, M.; Silva, M. R.; Salvador, R. P.; de Torresi, S. I. C.; Dall'Antonia, L. H.; Electrochimica Acta (2007), doi:10.1016/j.electacta.2007.11.029.

It is recommended to give composite references instead of a list of separate references. The style of composite references is as follows:

4. Varela, H.; Torresi, R. M.; J. Electrochem. Soc. 2000, 147, 665; Lemos, T. L. G.; Andrade, C. H. S.; Guimarães, A. M.; Wolter-Filho, W.; Braz-Filho, R.; J. Braz. Chem. Soc., 1996, 7, 123; Ângelo, A. C. D.; de Souza, A.; Morgon, N. H.; Sambrano, J. R.; Quim. Nova 2001, 24, 473.

Patents

Patents should be identified as follows (if possible, the Chemical Abstracts number should be given in parentheses):

5. Hashiba, I.; Ando, Y.; Kawakami, I.; Sakota, R.; Nagano, K.; Mori, T.; Jpn. Kokai Tokkyo Koho 79 73,771 1979. (CA 91:P193174v)

6. Kadin, S.B.; US Pat. 4,730,004 1988. (CA 110:P23729y)

7. Eberlin, M. N.; Mendes, M. A.; Sparrapan, R.; Kotiaho, T. Br PI 9.604.468-3, 1999.

Books

With editors 


\section{SOUTHERN BRAZILIAN JOURNAL OF CHEMISTRY}

8. Regitz, M. Multiple Bonds and Low Coordination in Phosphorus Chemistry; Regitz, M.; Scherer, O. J., eds.; Georg Thieme Verlag: Stuttgart, 1990, cap. 2.

Without editors

9. Cotton, F.A.: Wilkinson, G.; Advanced Inorganic Chemistry, 5th ed., Wiley: New York, 1988.

Computer programs (software)

10. Sheldrick, G. M.; SHELXL-93; Program for Crystal Structure Refinement; University of Gottingen, Germany, 1993.

Theses

11. Velandia, J. R.; Ph.D. thesis, Federal Rural University of Rio de Janeiro, Brazil, 1997.

Presentations at meetings

12. Ferreira, A. B; Brito, S. L.; Abstracts, 20th Annual Meeting of the Brazilian Chemical Society, Poços de Caldas, Brazil, 1998.

Internet pages

13. http://www.sbq.org.br/jbcs, accessed June 2001. (minimal of information requested)

Unpublished material

For articles accepted for publication: Magalhães, U. H.; J. Braz. Chem. Soc., in press.

For articles submitted but not yet accepted: Magalhães, U. H.; J. Braz. Chem. Soc., submitted.

For unpublished articles or personal communications: Magalhães, U. H.; unpublished or Magalhães, U. $\mathrm{H}$.; personal communication.

Unpublished results must only be cited with explicit permission from those who obtained them.

Whenever possible, authors should follow IUPAC recommendations (for all papers using chemical nomenclature) and use the International System of Units.

Figures: The number of figures (including graphs, diagrams, etc.) should not exceed 10 and should be submitted either in JPG or PNG formats. All photographs, graphs, and diagrams should be numbered consecutively (e.g., Figure 1) in the order in which they are referred to in the text. The caption must appear below the figure (size 11, bold, italic) and should be sufficiently detailed to enable to understand apart from the text. Explanation of lettering and symbols should be also given in the caption and only exceptionally in the figures. Figures should be of good quality and preferably in black and white. (Color figures will appear in the downloadable files, but all papers will be printed in black and white.) Scanned figures should be at a resolution of $800 \mathrm{dpi} / \mathrm{bitmap}$ for line graphs. Diagrams containing chemical structures should be of high graphical quality and always be of the same size so that they can be uniformly reduced. Figures should have a maximum width of one Journal column $(8.5 \mathrm{~cm})$ to be inserted on the body of the text so that they can be applied to the standards of the Journal. If the figures exceed $8.5 \mathrm{~cm}$, they will be placed at the end of the article. In addition, authors may be requested to submit each figure also as an image file in one of the following formats: jpg or png. For figures, graphs, diagrams, tables, etc., identical to material already published in the literature, authors should seek permission for publication from the companies or scientific societies holding the copyrights and send it to the editors of SBJChem along with the final form of the manuscript.

Tables: Tables should be self-explanatory. They should be mentioned in the text, numbered consecutively (e.g., Table 1) and accompanied by title at the top (size 11, bold, italic). Please insert all the tables in the text, do not enclose huge tables which cannot be fit within the page margins.

Mathematical expressions: In general, minimize unusual typographical requirements, use solidus, built-up fractions. Avoid lengthy equations that will take several lines (possibly by defining terms of the equation in separate displays). For drawing equations, please use the Equation Editor of Word, if possible. Make subscripts and superscripts clear. Display only those mathematical expressions that must be numbered for later reference 


\section{SOUTHERN BRAZILIAN JOURNAL OF CHEMISTRY}

or that need to be emphasized. The number displayed equations consecutively throughout the paper. The numbers should be placed in parentheses to the right of the equation, e.g. ( Eq. 1).

Supplementary material: Any Supplementary material (extra figures, tables, diagrams, etc.) should be placed at the end of the manuscript and clearly indicated as such. A single .pdf-document, including the supplementary material, should be submitted.

Editors, at any time of the editing process, may ask authors to split off part of the manuscript, presenting it as supplementary material.

We also accept references in the format of APA (American Psychological Association) and Chicago style. So if you use computer software to generate the references, this may be useful to you. The relevant part to us is to ensure that the reader will be able to locate your references if it is necessary.

\section{GUIDELINES FOR PUBLICATION}

All guidelines below are focused on Chemistry. However, if the manuscript that is going to be submitted is focused on another field, the same guidelines should be considered and applied to the subject of interest.

General - Articles suitable for publication in the Southern Brazilian journal of Chemistry are those that cover the traditional fields of Chemistry, Physics, Mathematics, Biology, Pharmacy, Medicine, Engineering and Agriculture. Articles on chemical the history of chemistry, science policy, etc., besides articles on related fields, are also accepted as long as they have a substantial content that has not been published previously in any other Journal. Articles should conform to one of the categories below:

Original Articles: for communicating original research. Articles should follow the usual form of presentation, including introduction, results, experimental section, etc., as appropriate for the work being submitted. They should have a maximum of 20 pages, including figures, tables, diagrams, etc. All pages should be numbered following the template.

Review Articles: for communicating progress in a specific field of chemistry, with the objective of providing a critical account of state of the art from the point of view of the highly qualified and experienced specialist. They should have a maximum of 40 pages, including figures, tables, diagrams, etc. All pages should be numbered following the template.

It is essential for authors to have publications in the field reviewed attesting their experience and qualification. Before submitting the manuscript, authors should send an e-mail to the editors with an abstract of the review and a letter explaining the relevance of the publication. The material will be examined by the editors and, once approved, and authors will be requested to submit the full manuscript, according to TQ guidelines. This manuscript will then be submitted to referees.

Technical Notes: for communicating methods, validation of methods, techniques, equipment, and accessories developed in the author's laboratory or according to the professional experience of the authors in checking some situations at the site. They should have a maximum of 25 pages, including figures, tables, diagrams, etc. All pages should be numbered following the template.

General Subjects: subjects of general interest for chemists, such as science policy, undergraduate and post-graduate programs, history of chemistry, etc. They should have a maximum of 40 pages, including figures, tables, diagrams, etc. All pages should be numbered following the template.

Interviews: for communicating interviews linked to one of the subjects of the interest of the Southern Brazilian journal of Chemistry. The interview should have a maximum of 20 questions or 15 pages. the person who is going to be interviewed does not necessarily need to be a researcher. It may be another person since the subject to be discussed shows relevance in the field of science. All pages should be numbered following the template. 


\section{SOUTHERN BRAZILIAN JOURNAL OF CHEMISTRY}

\section{HOW TO SUBMIT A MANUSCRIPT?}

The Southern Brazilian Journal of Chemistry publishes original research papers, review articles, short communications (scientific publications), book reviews, forum articles, technical reports, interviews, announcements or letters. Researchers from all countries are invited to publish on its pages. Manuscripts (of scientific publications) should present new scientific findings that have not been published before and are not submitted for publication elsewhere.

Papers must be in English. All manuscripts are peer-reviewed by at least two independent referees. Papers accepted for publication by the editorial board are subject to editorial revision.

Public agreement for publishing.

1) The authors declare that the submitted manuscript is their own work, which has not been published anywhere else before and that they are not willing to publish it anywhere later.

2) The authors take responsibility for the content of the publication.

3) It is the responsibility of the author to obtain written permission for reproducing illustrations or tables from other published material.

4) The authors and the journal agree that the journal publishes the reviewed and accepted manuscript after technical construction in printed and in electronic form.

5) The authors and the journal agree not to lay any claim to financial demand.

6) The authors can ask for amendment or errata related to the publication, which will be published in the subsequent edition of the journal in maximum one page. Other additions or remarks to the article after publication will be judged by the editorial board.

7) The authors will transfer copyright to the publisher of SBJChem.

8) This agreement for publication will become lawful on the author's side from submitting the manuscript, on the journal's side from the announcement of the publication's acceptance. In the case this procedure occurs through electronic channels, this agreement is valid without an additional signed copy.

Submission of manuscripts

To ensure rapid publication, the submission of a single file of the complete manuscript either in .doc or .odt format should be sent to southbchem@gmail.com. After the submission has been checked by the editors, an e-mail will be sent with suitable information.

On submitting an article, the cover letter is requested in the same e-mail message. In this letter, the emails of all authors as well as all information regarding the article like the title, name, and the address of the authors must be given.

In the case of multiple authors, the corresponding author should be indicated. He/She will be notified of acceptance, rejection, or need for revision. Manuscripts will not be returned to an author unless specifically requested, or unless reviewers have provided annotations that will be useful to the author. 